\title{
Mineral transformations and textural evolution during roasting of bog iron ores
}

\author{
Grzegorz Rzepa $^{1} \cdot$ Tomasz Bajda $^{1} \cdot$ Adam Gawel $^{1} \cdot$ Klaudia Debiec $^{2} \cdot$ \\ Lukasz Drewniak ${ }^{2}$
}

Received: 28 January 2015/ Accepted: 2 July 2015/Published online: 15 July 2015

(c) The Author(s) 2015. This article is published with open access at Springerlink.com

\begin{abstract}
The processes occurring during roasting of bog iron ores were characterized using TG-DTG-DTA-QMS, XRD, FTIR and specific surface analysis. Removal of physically adsorbed water is followed by dehydroxylation of iron oxyhydroxides and oxidation of organic matter at $200-600{ }^{\circ} \mathrm{C}$. The main product of the transformations is disordered nanocrystalline (proto)hematite or hematite/maghemite mixture, depending on organic matter content and heating conditions. The conversion of iron oxyhydroxides to hematite occurs at temperatures different than those reported for pure compounds. At higher temperatures, protohematite undergoes recrystallization to the stoichiometric hematite, and manganese oxides are partially reduced. At $1000{ }^{\circ} \mathrm{C}$, the roasting products consist of hematite and cristobalite together with $\mathrm{Mn}-\mathrm{Fe}$ spinels if the initial ore contained Mn oxides. The admixtures of various secondary silicates were encountered as well. Low- to moderate-temperature roasting slightly affects the specific surface area and lowers volume of micropores. The hightemperature transformations lead to decrease in the specific surface area and to the destruction of porous texture of the bog iron ores. Although the general course of the processes during roasting was similar in all the samples, some of their details as well as mineralogy and properties of the products
\end{abstract}

Grzegorz Rzepa

gprzepa@cyf-kr.edu.pl

1 Department of Mineralogy, Petrography and Geochemistry, Faculty of Geology, Geophysics and Environmental Protection, AGH University of Science and Technology, al. A. Mickiewicza 30, 30-059 Krakow, Poland

2 Laboratory of Environmental Pollution Analysis, Faculty of Biology, University of Warsaw, ul. Miecznikowa 1, 02-096 Warsaw, Poland are highly dependent on the composition of the initial material.

Keywords Iron (oxyhydr)oxides · Ferrihydrite · Goethite $\cdot$ Hematite $\cdot$ Surface properties

\section{Introduction}

Iron oxides and oxyhydroxides are important $\mathrm{Fe}$ carriers in the Earth's crust, especially in near-surface environments [1], and the only iron ores used at present. Their chemistry, crystal structure and surface properties cause that these minerals play major role in near-surface environments, strongly influencing, among others, (bio)geochemical cycling of many major and trace elements. Some of the (oxyhydr)oxides, particularly those containing water molecules and/or hydroxyl groups, are transformed at elevated temperatures. These include ferrihydrite $\left(5 \mathrm{Fe}_{2} \mathrm{O}_{3} \cdot 9 \mathrm{H}_{2} \mathrm{O}\right.$ or $\left.\mathrm{Fe}_{5} \mathrm{HO}_{8} \cdot 4 \mathrm{H}_{2} \mathrm{O}\right)$, goethite $(\alpha-\mathrm{FeOOH})$, lepidocrocite $(\gamma-\mathrm{FeOOH})$, akaganéite $[\beta-\mathrm{FeO}(\mathrm{OH}, \mathrm{Cl})]$, feroxyhite $\left(\delta^{\prime}-\mathrm{FeOOH}\right)$ and schwertmannite $\left[\mathrm{Fe}_{8} \mathrm{O}_{8}(\mathrm{OH})_{6}\left(\mathrm{SO}_{4}\right) \cdot \mathrm{nH}_{2} \mathrm{O}\right]$. Some oxides, like maghemite $\left(\gamma-\mathrm{Fe}_{2} \mathrm{O}_{3}\right)$, may be affected as well. In oxidizing conditions, the $\mathrm{Fe}(\mathrm{II})$-containing compounds, like magnetite $\left(\mathrm{Fe}_{3} \mathrm{O}_{4}\right)$, can be easily oxidized, even (when being ultrafine) at room temperature $[1,2]$. Hematite $\left(\alpha-\mathrm{Fe}_{2} \mathrm{O}_{3}\right)$ is usually the final product of such transformations. Although the overall course of the processes is widely known, the effects of various crystal-chemical and chemical factors on the transformation mechanisms and properties of the products are still under vigorous debate [1,3]. This type of research focuses usually on monomineral synthetic samples [e.g., 4-10] and does not fully reflect the complexity of the processes during thermal transformations of natural 
Fe-oxide-rich materials [e.g., 10-17], archeological findings $[18,19]$ and composite industrial products or wastes [20-22]. A good example of such a complex system are bog iron ores.

Bog iron ores are Holocene terrestrial iron accumulations occurring in wet, shallow depressions, several centimeters below the land surface, within the zone of groundwater oscillation [23-25]. Their occurrences were reported in many regions of northern Europe, Asia and North America [25-33]. In the past, bog iron ores were used in iron metallurgy [24, 28, 34-36], as pigments $[24,37]$ and even as building material [24, 38-40]. The composition of bog iron ores combined with their porous structure results in complex surface chemistry and large specific surface areas. Therefore, these mineral raw materials have been used as sorbents for removing hydrogen sulfide and hydrogen cyanide from flue gases and biogas [41-45] and have also been recently investigated as heavy metal sorbents [46, 47].

Bog iron ores can be divided into two main types: fine (or "soft") ores, representing a loose deposit, and cemented (lump or "hard") ores, resembling slag or ferruginous sandstone in hand specimens [24, 25, 46]. The ores form cryptocrystalline "limonite," which consists predominately of the iron oxyhydroxides: ferrihydrite, goethite, and sometimes lepidocrocite. These are accompanied by variable amounts of siliciclastic material (like quartz and feldspars). Poorly crystalline hydrous manganese oxides, mainly vernadite $\left(\mathrm{MnO}_{2} \cdot \mathrm{nH}_{2} \mathrm{O}\right)$ type $[24,46]$, are also encountered. Under reducing conditions and at elevated content of organic matter, iron phosphates [predominately vivianite, $\left.\mathrm{Fe}_{3}\left(\mathrm{PO}_{4}\right)_{2} \cdot 8 \mathrm{H}_{2} \mathrm{O}\right]$ and carbonates (siderite, $\mathrm{FeCO}_{3}$ and various $\mathrm{Mn}-\mathrm{Ca}-\mathrm{Fe}$ carbonates) can be formed $[24,31,37]$. Pyrite $\left(\mathrm{FeS}_{2}\right)$ was reported in some areas as well [26, 27, 48, 49]. Although iron oxide, hematite $\left(\mathrm{Fe}_{2} \mathrm{O}_{3}\right)$, was occasionally encountered [23], it originated from peat-bog fires or meadow burnings [24]. Magnetite $\left(\mathrm{Fe}_{3} \mathrm{O}_{4}\right)$ in turn may be a product of bacterial reduction [23]. An important constituent of most bog iron ores is also organic matter, exhibiting variable chemistry and maturity [24].

Utilization of bog iron ores as natural mineral sorbents meets an important problem of lacking simple correlation between their (chemical and mineral) composition and surface properties or sorption capacity [47]. Although the uptake of heavy metals by the ores is controlled mainly by iron oxyhydroxides, the processes are considerably modified by numerous ions (mainly silicate, phosphate and organic anions) associated with the mineral surfaces. Also, bog iron ores contain a significant amount of organic matter-up to 15 mass \% of organic carbon was reported in some "fine" ores $[24,46]$. The presence of organic matter and other "active" substances, like manganese oxides, causes further complications in the sorption mechanisms.
Both organic matter and manganese oxides are also capable of binding various pollutants, such as trace metals, and other inorganic and organic compounds. A complex organic-mineral system is formed, which provides various types of active centers that play role in sorption processes [47]. Hence, a specific pollutant adsorption mechanism depends strongly on mutual interactions of the components of bog iron ore. In order to improve the sorption capacity and also to enhance predictability of the influence of mineral composition on the amount of bound metals, some bog iron ore treatments were considered. The treatments include the removal of organic matter which was considered as possibly blocking active sorption centers on the surface of iron oxyhydroxides $[50,51]$. The simplest way to achieve the removal of organic matter is roasting the material in oxidizing conditions. However, the method is also the most invasive because it affects mineral composition, predominately due to dehydration and dehydroxylation of iron oxyhydroxides, the most important sorptionactive constituents of bog iron ore.

The study is aimed at the evaluation of the impact of the temperature conditions on thermal transformations in a complex, mineral-organic system on the example of a bog iron ore. As already mentioned, the alterations of the initial compounds during heating of natural multi-component materials proceed via much more intricate pathways than those observed when pure, synthetic materials are annealed. Therefore, thorough studies in this area are still scarce, and detailed tracking of the thermal processes taking place in the course of roasting bog iron ores may shed more light on the problem. Also, recognition of the properties of the resulting products should allow the selection of proper temperature conditions of roasting to achieve an expected improvement of bog iron ore sorption properties. It might be helpful in estimating the temperature condition that affected natural ferruginous materials in the past during intentional thermal treatment (e.g., when used as mineral pigments or during pre-enrichment of ores prior to metallurgical processes) or during natural thermal events as fires of peat-bogs, moors, forests or meadows.

\section{Experimental}

\section{Materials}

Four samples of bog iron ores from deposits located in Poland were selected for this study. The samples Dębe Małe (DM-f) and Kolechowice (KOL) represent fine ores, while the samples Dębe Małe (DM-l) and Grady Dolne (GD) are lump ores. A brief mineralogical and chemical description of the samples is summarized in Table 1. They consist predominately of poorly crystalline ferric oxyhydroxides 
Table 1 Chemical and mineralogical characteristics of the samples [47, 54]

\begin{tabular}{|c|c|c|c|c|}
\hline & $\begin{array}{l}\text { Dębe Małe } \\
\text { DM-f }\end{array}$ & $\begin{array}{l}\text { Dębe Małe } \\
\text { DM-1 }\end{array}$ & $\begin{array}{l}\text { Kolechowice } \\
\text { KOL }\end{array}$ & $\begin{array}{l}\text { Grądy Dolne } \\
\text { GD }\end{array}$ \\
\hline $\mathrm{SiO}_{2}$ & 15.00 & 4.02 & 7.88 & 22.81 \\
\hline $\mathrm{TiO}_{2}$ & 0.09 & 0.02 & 0.02 & 0.11 \\
\hline $\mathrm{MnO}_{2}$ & 0.65 & 2.03 & 0.27 & 15.25 \\
\hline $\mathrm{Al}_{2} \mathrm{O}_{3}$ & 1.62 & 0.37 & 0.28 & 1.02 \\
\hline $\mathrm{Fe}_{2} \mathrm{O}_{3}$ & 39.16 & 63.18 & 47.93 & 43.72 \\
\hline $\mathrm{FeO}$ & 0.17 & 0.40 & 0.49 & 0.08 \\
\hline $\mathrm{CaO}$ & 2.91 & 2.87 & 2.63 & 1.72 \\
\hline $\mathrm{MgO}$ & 0.20 & 2.51 & 0.08 & 0.27 \\
\hline $\mathrm{Na}_{2} \mathrm{O}$ & 0.12 & 0.04 & 0.04 & 0.15 \\
\hline $\mathrm{K}_{2} \mathrm{O}$ & 0.27 & 0.07 & 0.07 & 0.32 \\
\hline $\mathrm{P}_{2} \mathrm{O}_{5}$ & 5.59 & 7.68 & 3.11 & 2.87 \\
\hline $\mathrm{H}_{2} \mathrm{O}^{+}$ & 9.15 & 9.33 & n.a. & 7.34 \\
\hline LOI & 23.82 & 6.55 & 35.60 & 4.02 \\
\hline $\mathrm{BET} / \mathrm{m}^{2} \mathrm{~g}^{-1}$ & 99 & 242 & 152 & 154 \\
\hline $\mathrm{Fe}_{\mathrm{DCB}} / \mathrm{mass} \%$ & 27.41 & 41.57 & 31.93 & 28.85 \\
\hline $\mathrm{Fe}_{\mathrm{OX}} / \mathrm{mass} \%$ & 21.06 & 37.01 & 4.94 & 14.45 \\
\hline $\mathrm{C}_{\text {tot }} /$ mass $\%$ & 11.30 & 2.74 & 8.75 & 1.17 \\
\hline Mineralogy & $\underline{\mathrm{Fh}}, \underline{\mathrm{Q}}, \mathrm{Gt}, \mathrm{P}, \mathrm{Mn}$ & $\underline{\mathrm{Fh}}, \underline{\mathrm{Gt}}, \mathrm{Q}, \mathrm{V}, \mathrm{Mn}$ & $\underline{\mathrm{Fh}}, \underline{\mathrm{Q}}, \underline{\mathrm{Gt}}, \mathrm{P}$ & $\underline{\mathrm{Fh}}, \underline{\mathrm{Q}}, \underline{\mathrm{Gt}}, \underline{\mathrm{Mn}}$ \\
\hline
\end{tabular}

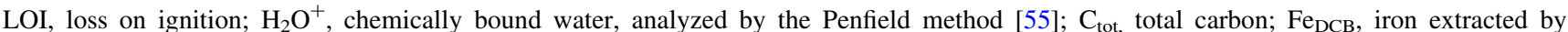
dithionite-citrate-bicarbonate method [56]; $\mathrm{Fe}_{\mathrm{OX}}$, iron extracted in acid ammonium oxalate [52]; Fh, ferrihydrite; Gt, goethite; P, amorphous phosphates; Mn, manganese oxides; V, vivianite (main phases underlined)

(ferrihydrite and goethite) with variable admixture of siliciclastic material (mainly quartz). High ratio of the oxalateto dithionite-extracted $\mathrm{Fe}$ indicates high proportion of ferrihydrite among Fe carriers [52, 53]. Manganese oxides (vernadite) are important constituents of the GD sample, while small amounts of (partly oxidized) vivianite and/or amorphous iron phosphates are found in the remaining samples. The organic matter is an important component of the fine ores (DM-f and KOL), which is reflected by distinctly high total carbon concentrations (Table 1).

\section{Analytical methods}

The natural samples were characterized using X-ray powder diffraction (XRD) and thermal analyses (DTA/ DTG/TG). Because thermal analyses were carried out in dynamic mode (with constant heating rate), they results could not be used to estimate the reaction temperatures. Therefore, in order to obtain detailed data on the phase transformations, the samples were heated in a muffle furnace at the temperature conditions of $150,200,250,300$, $350,400,450,500,550,600,700,800,900$ and $1000{ }^{\circ} \mathrm{C}$ (sample KOL) or $200,300,500,700,1000{ }^{\circ} \mathrm{C}$ (the rest of the samples) for an hour. After cooling, the roasted samples were analyzed by XRD and by FTIR in the case of
KOL sample. Surface area and porosity of the natural and preheated (at 200, 400, 700 and $1000^{\circ} \mathrm{C}$ ) $\mathrm{KOL}$ sample were also measured.

X-ray diffraction patterns were collected using Rigaku SmartLab instrument equipped with a graphite monochromator, rotation $\mathrm{Cu}$ anode, $45 \mathrm{kV}$ and $200 \mathrm{~mA}$ generator settings, $2-75^{\circ} 2 \theta$ recording range, $0.05^{\circ}$ step size and counting time of $1 \mathrm{~s}$ per step. Eliminating an influence of instrumental parameters on peak intensities was achieved by adjusting the primary beam value using plano-parallel plate cut from the highly crystalline Brazilian quartz specimen prior to each analysis. The XRD patterns were processed with XRAYAN software using the diffraction pattern database of the International Centre for Diffraction Data [57]. X-ray diffractometry allowed to obtain qualitative mineralogical data. However, quantitative Rietveld analysis was not applied, because of high contents of amorphous or nearly amorphous substances of both organic and mineral types in the bog iron ores. Their presence renders the quantitative analysis hardly reliable, and they cannot be removed prior to measurements because they represent the major components of the samples.

In order to support the results of XRD analyses, the Fourier-transformed infrared (FTIR) spectra of the KOL sample annealed at 150, 200, 250, 300, 350, 400, 500, 700, 
800 and $1000{ }^{\circ} \mathrm{C}$ were collected in the range of $400-4000 \mathrm{~cm}^{-1}$. The spectra were obtained applying Bruker Tensor 27 spectrometer. Prior to analysis, $\mathrm{KBr}$ pellets were obtained by homogenizing $200 \mathrm{mg}$ of ground $\mathrm{KBr}$ with $4 \mathrm{mg}$ of the sample.

Simultaneous thermogravimetric (TG) and differential thermal analysis (DTA) measurements, below referred to STA, were taken using Netzsch STA 449F3 Jupiter apparatus. Fifty milligrams of an air-dried sample was heated from 20 to $1000{ }^{\circ} \mathrm{C}$ in an alumina crucible, at $10{ }^{\circ} \mathrm{C} \mathrm{min}{ }^{-1}$ in flowing $\left(40 \mathrm{~mL} \mathrm{~min}^{-1}\right)$ synthetic air. In order to ensure similar heat capacity and heat conductivity, hematite obtained by annealing of synthetic 2-line ferrihydrite at $1000{ }^{\circ} \mathrm{C}$ was used as an inert (reference) material. Applying of hematite involves an inconvenience consisting in an additional exotherm appearing on DTA curves (discussed below). Nevertheless, the overall shape of the DTA curve is substantially more legible than with $\mathrm{Al}_{2} \mathrm{O}_{3}$ used as the reference. Analyses of the evolved gases were carried out using quadrupole mass spectrometer-Netzsch QMS 403C Aëolos.

The porous texture properties (surface area and porosity) of the natural and preheated KOL sample were evaluated using Micrometrics ASAP 2020 instrument, by low-temperature (at $-196{ }^{\circ} \mathrm{C}$ ) nitrogen adsorption and desorption study, applying Brunauer-Emmet-Teller [58] isotherm. Prior to analysis, the samples were outgassed at $90{ }^{\circ} \mathrm{C}$ for $12 \mathrm{~h}$, i.e., under conditions preventing thermal transformation of poorly ordered iron oxyhydroxides [59, 60].

\section{Results and discussion}

\section{Coupled STA-QMS analysis}

The DTA-TG-DTG curves of all bog iron ores studied show similar patterns (Fig. 1). The surface-adsorbed water was removed at lower temperatures $\left(<\right.$ cca. $\left.200{ }^{\circ} \mathrm{C}\right)$. The dehydration was completed at temperatures from cca. 190$195{ }^{\circ} \mathrm{C}$ (DM-f, KOL and GD samples) to cca. $210{ }^{\circ} \mathrm{C}$ (sample DM-1). In this temperature range, the lowest mass loss was recorded in sample GD ( $\sim 7$ mass $\%)$, while the rest of the samples exhibit slightly higher losses of 10-13 mass $\%$. Such variability is related to the differences in phase composition of the bog iron ores. Here, the most effective humidity adsorbents are iron oxyhydroxides and organic matter and the total content of these constituents is the lowest in GD sample (Table 1). Another mass loss, recorded above cca. $200{ }^{\circ} \mathrm{C}$, is related to dehydration and dehydroxylation of iron oxyhydroxides as well as oxidation of organic matter, according to following simplified reactions:
$2 \mathrm{FeOOH}$ (goethite) $\rightarrow \mathrm{Fe}_{2} \mathrm{O}_{3}+\mathrm{H}_{2} \mathrm{O}$

$2 \mathrm{Fe}_{5} \mathrm{HO}_{8} \cdot 4 \mathrm{H}_{2} \mathrm{O}$ (ferrihydrite) $\rightarrow 5 \mathrm{Fe}_{2} \mathrm{O}_{3}+5 \mathrm{H}_{2} \mathrm{O}$

$\mathrm{CH}_{2} \mathrm{O}$ (organic matter) $+\mathrm{O}_{2} \rightarrow \mathrm{CO}_{2}+\mathrm{H}_{2} \mathrm{O}$

In the case of GD sample, dehydration of manganese oxides is also involved:

$\mathrm{MnO}_{2} \cdot \mathrm{nH}_{2} \mathrm{O}$ (vernadite) $\rightarrow \mathrm{MnO}_{2}+\mathrm{nH}_{2} \mathrm{O}$

QMS signals of $\mathrm{H}_{2} \mathrm{O}$ and $\mathrm{CO}_{2}$ (Fig. 1) indicate that dehydration and dehydroxylation processes were initiated at slightly lower temperatures than organic matter oxidation. The bend of DTG curve, accompanying oxyhydroxides dehydroxylation (which is evidenced by corresponding QMS signal of $\mathrm{H}_{2} \mathrm{O}$ ), has a minimum at $240-260{ }^{\circ} \mathrm{C}$ (Fig. 1). However, an endotherm related to this reaction is visible on DTA curve only when heating is carried out in inert (e.g., $\mathrm{N}_{2}$ ) atmosphere or when the sample was treated with concentrated $\mathrm{H}_{2} \mathrm{O}_{2}$ prior to the measurements (data not presented here). Otherwise, the endotherm is overlapped by a large exotherm of organic matter oxidation with a maximum at $300-310{ }^{\circ} \mathrm{C}$. It should be noted that the latter peak is distinctly sharper for the fine bog iron ores (DM-f and KOL) than for the lump bog iron ores (GD and DM-1), which can be related to significantly higher content of total carbon and thus of organic matter in fine ores (Table 1). Also, organic matter is less matured in these samples than in lump bog ores [54], and consequently, it is oxidized in narrower temperature range. The mass losses accompanying these reactions in the fine ores are substantially larger as well (ca. 14.5 mass\% for DM-f and ca. 23.5 mass \% for KOL in comparison with ca. 5.5 mass\% for GD and ca. 9 mass\% for DM-1). At higher temperatures, the bog iron ores loose additional 1-2 mass\% which is usually attributed to clay and/or carbonate admixtures, but DTG curves are featureless. This loss may be also related to gradual expelling of hydroxyls from non-stoichiometric (proto)hematite (see the discussion below). In the case of GD sample only, a small mass loss (1.0 mass\%) on DTG curve was recorded at $625-875^{\circ} \mathrm{C}$, which is related to reduction of $\mathrm{Mn}^{4+}$ to $\mathrm{Mn}^{3+}$ in manganese oxides and simultaneous $\mathrm{O}_{2}$ emanation $[61,62]$ :

$2 \mathrm{MnO}_{2} \rightarrow \mathrm{Mn}_{2} \mathrm{O}_{3}+1 / 2 \mathrm{O}_{2}$

The subsequent partial reduction to $\mathrm{Mn}^{2+}$ is also possible at higher $\left(\sim 900{ }^{\circ} \mathrm{C}\right)$ temperature $[63,64]$ :

$3 \mathrm{Mn}_{2} \mathrm{O}_{3} \rightarrow 2 \mathrm{Mn}_{3} \mathrm{O}_{4}+1 / 2 \mathrm{O}_{2}$

The mass loss related to this reaction is approximately three times smaller than that related to the first reduction, so it is virtually unrecognizable on the both DTA and DTG curves, but an additional mass loss above $875^{\circ} \mathrm{C}$ ( $\sim 0.3$ mass $\%$ ) was recorded. Assuming 15.25 mass $\%$ of 

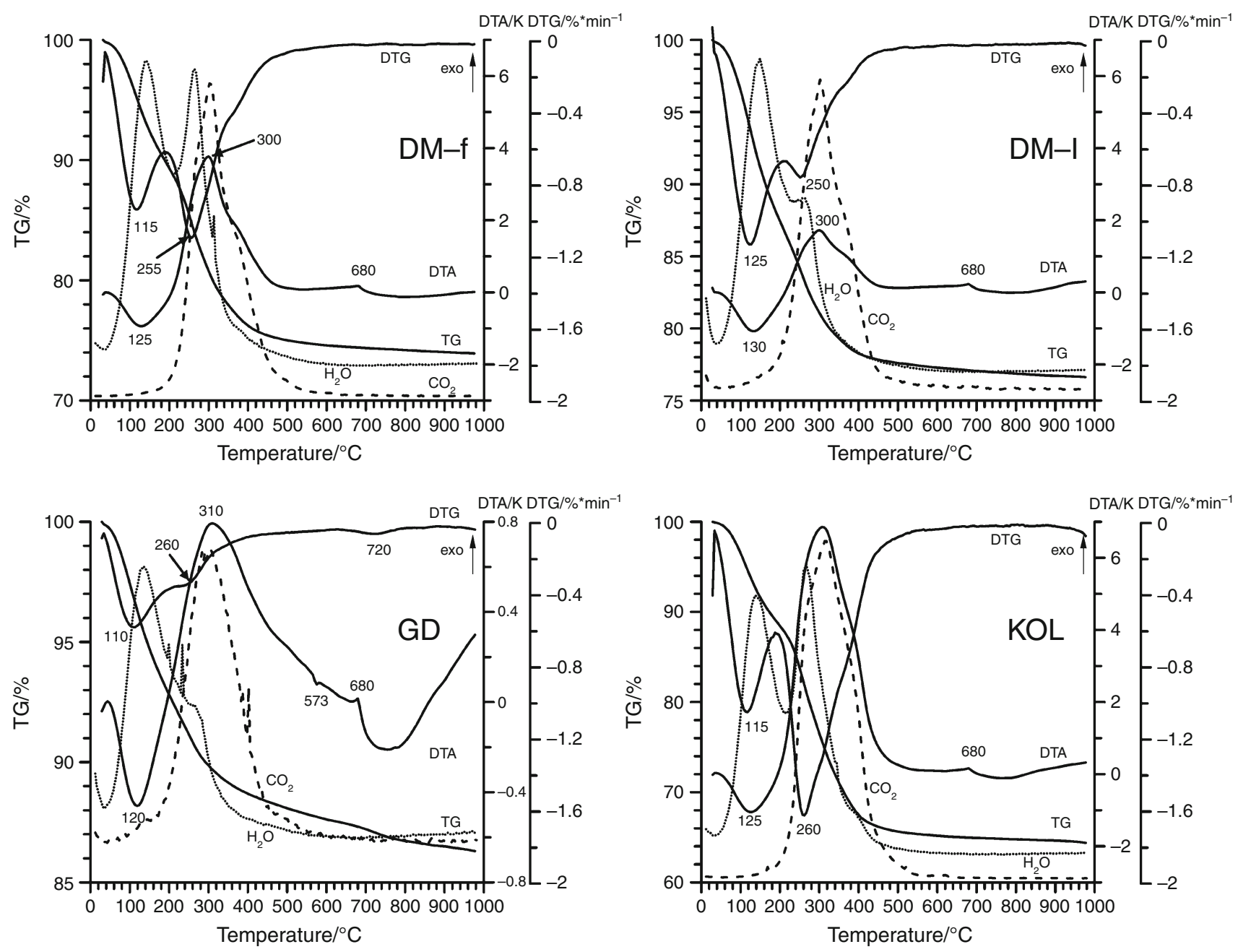

Fig. 1 DTA-TG-DTG plots of the bog iron ores. a DM-f, b DM-1, c GD, d KOL. QMS signals (not-to scale, dashed lines) of $\mathrm{H}_{2} \mathrm{O}$ and $\mathrm{CO}_{2}$ are shown as well. The numbers denote temperatures of processes/reactions. Note a different DTA scale for the GD sample

$\mathrm{MnO}_{2}$ present in the sample (Table 1), the overall mass loss related to manganese reduction would equal to $\sim 1.9$ mass $\%$, which is somewhat higher than observed value of $1.3 \%$. Thus, manganese oxides in the GD sample are probably of mixed $\mathrm{Mn}^{3+} / \mathrm{Mn}^{4+}$ type and/or a portion of Mn substitutes Fe in iron (oxyhydr)oxides. Furthermore, a sharp $573{ }^{\circ} \mathrm{C}$ peak related to the conversion of quartz- $\alpha$ to quartz- $\beta$ was recognized on the DTA curve of the GD sample, which is in accordance with the relatively highest $\mathrm{SiO}_{2}$ content shown by chemical analysis (Table 1). A distinct bend of all DTA curves at $675-680{ }^{\circ} \mathrm{C}$ is an effect of applying hematite as an inert material, because this is the Néel point of the oxide $[1,14,62]$. Total mass loss is the lowest in the lump bog iron ore GD (13.7 mass\%) and the highest in the fine bog iron ore KOL (35.61 mass\%). Samples DM-f and DM-1 exhibit intermediate values of 26.08 and 23.38 mass $\%$, respectively. This is because fine bog iron ores contain much more organic matter (total carbon contents reach cca. 10 mass\%, Table 1) than lump ones $\left(C_{\text {tot }}\right.$ cca. 1-3 mass $\left.\%\right)$, and the ferric oxyhydroxide amounts are relatively similar. The GD sample, exhibiting the lowest total mass loss, is enriched in detrital material (i.e., quartz and feldspars) and contains the least of organic matter comparing to the rest of the samples.

\section{XRD and FTIR analyses}

XRD patterns of the natural bog iron ores are grouped in Fig. 2. Diffractogram of a synthetic 6-line ferrihydrite obtained by the hydrolysis of acid ferric nitrate solution [1] is also plotted here for comparison. All the samples exhibit very broad diffraction peaks at $2 \theta$ angles of cca. $32^{\circ}-37^{\circ}$, $39^{\circ}-42^{\circ}, 45^{\circ}-47^{\circ}, 52^{\circ}-55^{\circ}$ and $60^{\circ}-64^{\circ}$ (marked by Fh symbol below the patterns) attributable to the oxyhydroxide presence [1]. This is consistent with the results of selective chemical extractions (Table 1), indicating 


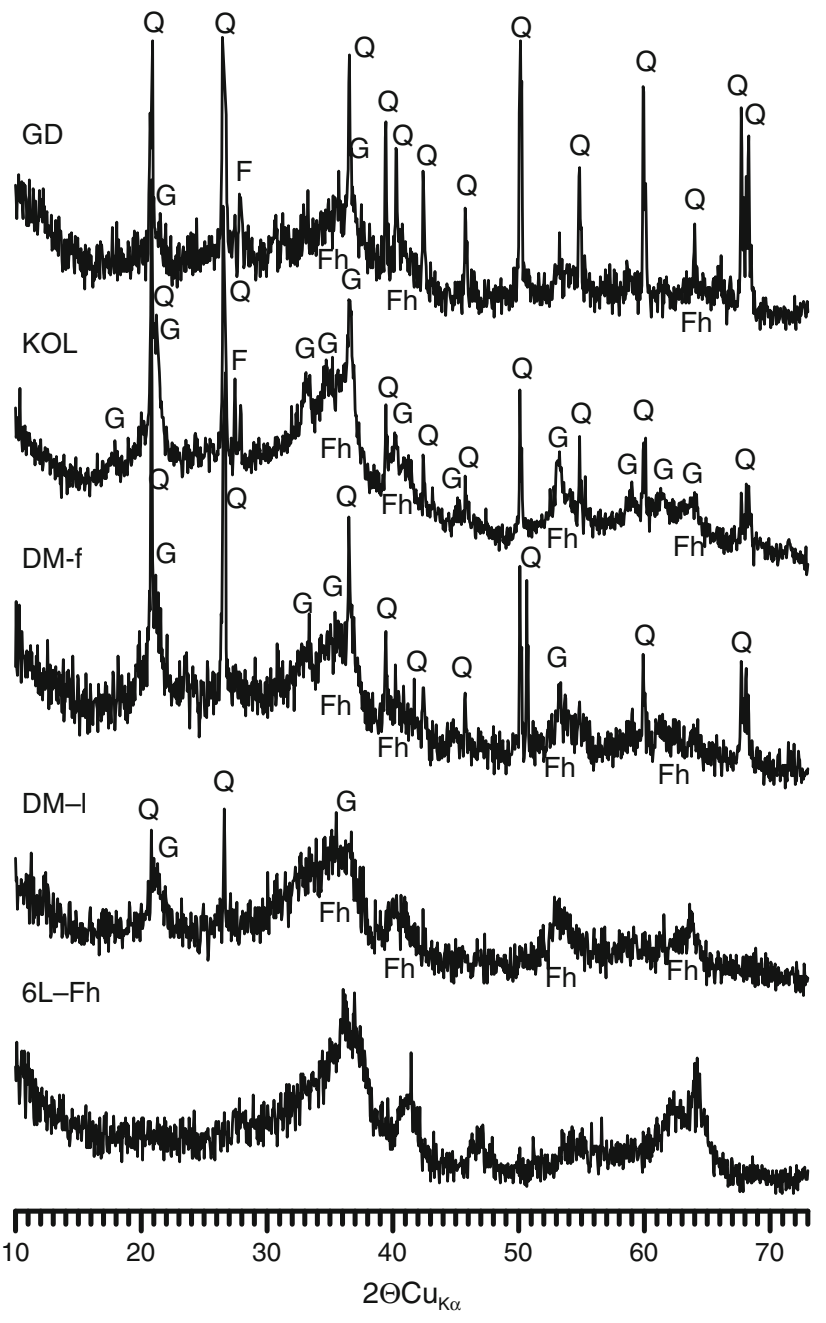

Fig. 2 XRD patterns of the natural (non-roasted) bog iron ores and synthetic 6-line ferrihydrite. Explanations: $F$ feldspar, $F h$ ferrihydrite, $G$ goethite, $Q$ quartz

substantial ferrihydrite concentrations in the bog iron ores. The ores contain poorly crystalline goethite as well, which is accompanied by a series of the oxyhydroxide peaks present in the XRD pattern of the KOL sample, and some single peaks observed on the diffractograms of the other samples. Siliciclastic detrital material, i.e., quartz and feldspars, are also highlighted in the XRD patterns (Fig. 2). The rest of the components listed in Table 1 were recognized on the basis of an optical microscopy and scanning electron microscopy observations (data not presented here $[24,54])$.

Infrared spectra of the natural and heated KOL sample are presented in Fig. 3. Very broad band with the maximum at $\sim 450-470 \mathrm{~cm}^{-1}$, and a shoulder $\sim 680 \mathrm{~cm}^{-1}$, visible at the spectra of unheated and annealed at $150{ }^{\circ} \mathrm{C}$ sample is typical for ferrihydrite $[65,66]$. Distinct bands at cca. 3385 and $1635 \mathrm{~cm}^{-1}$ are assigned to the stretching and

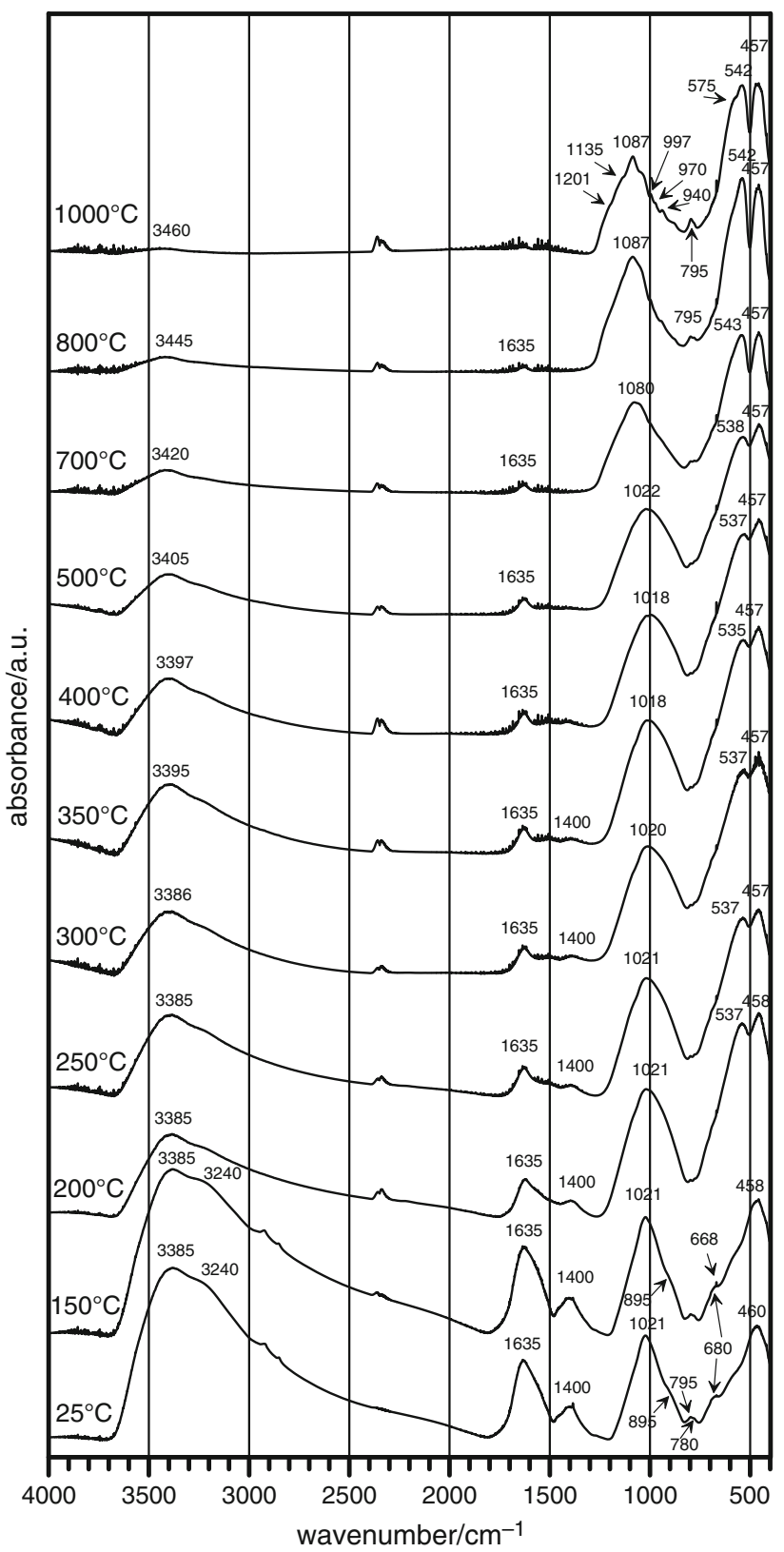

Fig. 3 Background-corrected FTIR spectra of the natural (nonroasted) and roasted KOL sample. The numbers denote position of the absorption bands

bending OH vibrations, respectively [67-69]. Another strong band occurs at $1020 \mathrm{~cm}^{-1}$. Silicates and/or phosphates may absorb infrared radiation in this region [65], and both these compounds are present in the sample (Table 1). The band was noticed in the spectra of essentially all bog iron ores [54]. A minor doublet at 780 and $800 \mathrm{~cm}^{-1}$ is diagnostic for small quartz admixture [65]. Goethite is poorly noticeable-apart from strong $\mathrm{Fe}-\mathrm{O}$ band at cca. $460 \mathrm{~cm}^{-1}$, shared with ferrihydrite, only two shoulders at cca. $895-900$ and $3200-3240 \mathrm{~cm}^{-1}$ are 
observed (Fig. 3). The shift of the latter from the reference $3140-3160 \mathrm{~cm}^{-1}$ position $[1,70]$ can be an effect of poor crystallinity of the oxyhydroxide. Organic matter is responsible for a broad band at cca. $1400 \mathrm{~cm}^{-1}$ [65]. A doublet at $2360-2340 \mathrm{~cm}^{-1}$, as well as sharp peak at $668 \mathrm{~cm}^{-1}$, occurring in most of the spectra, is related to antisymmetric stretching of the $\mathrm{CO}_{2}$ molecule [70] and is not an inherent feature of the samples.

The first signs of phase transformations occur at the temperature as low as $200{ }^{\circ} \mathrm{C}$ (Figs. 3-7). The FTIR

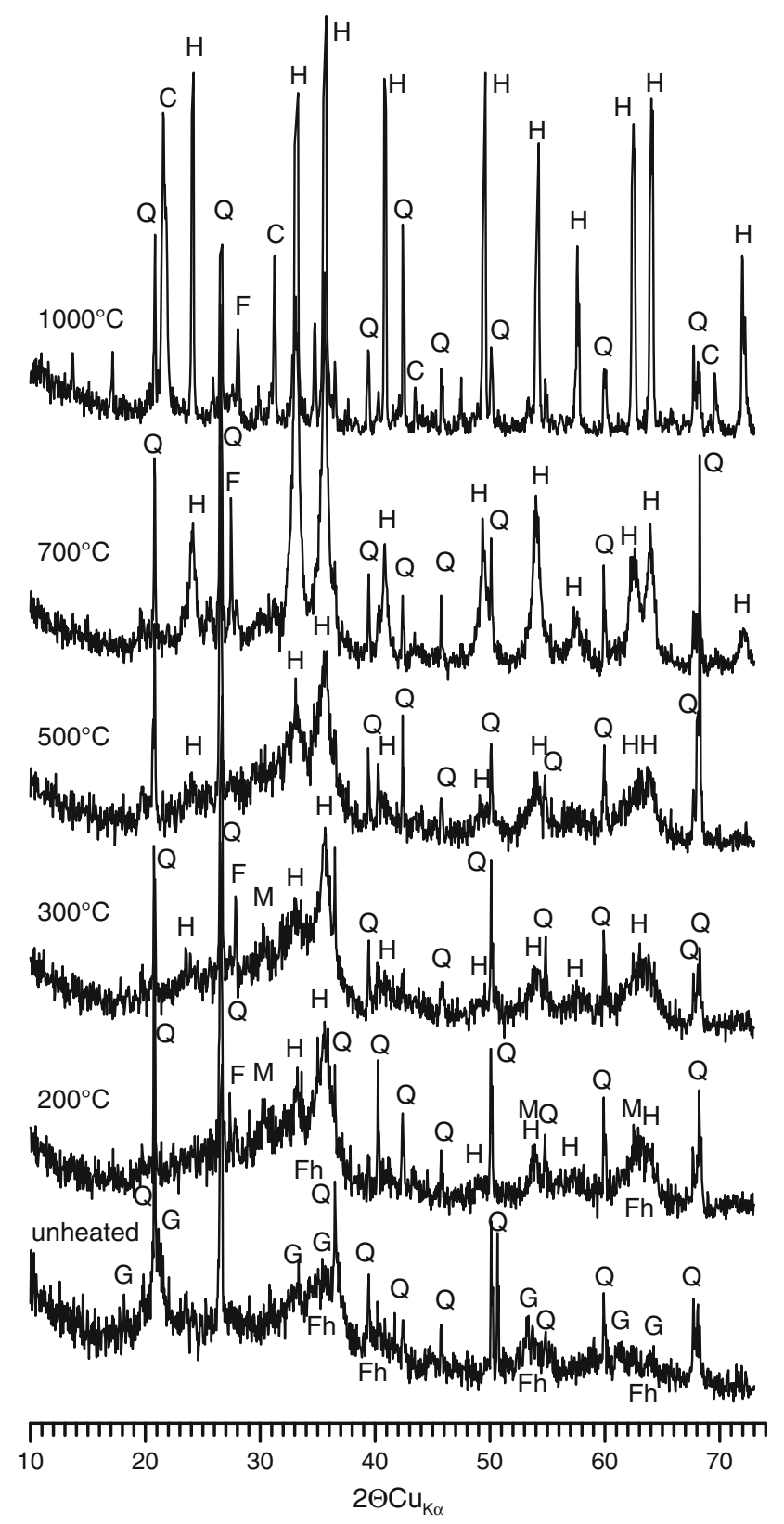

Fig. 4 XRD patterns of sample DM-f heated at different temperatures. Explanations: $C$ cristobalite-like phase, $F$ feldspar, $F h$ ferrihydrite, $G$ goethite, $H$ hematite, $M$ maghemite, $Q$ quartz

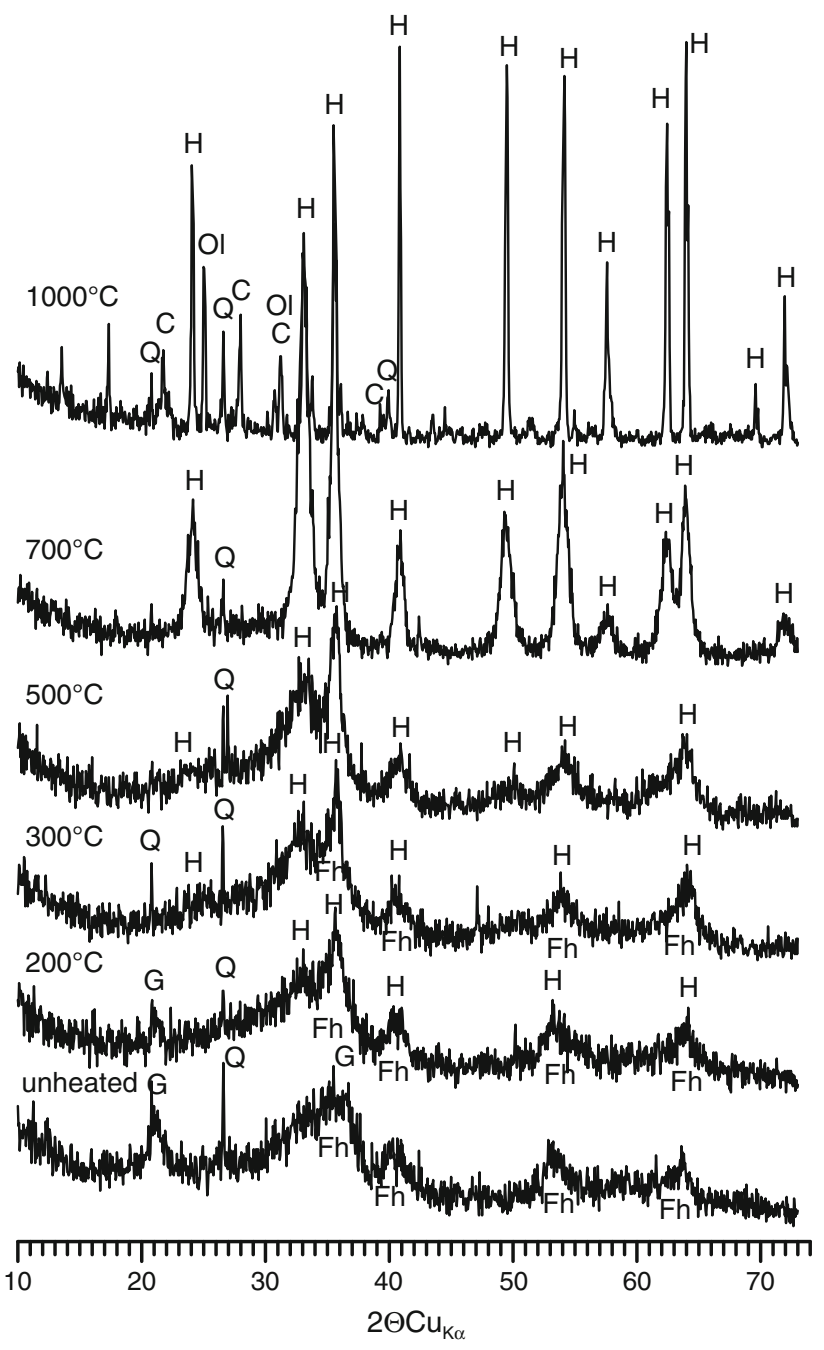

Fig. 5 XRD patterns of sample DM-1 heated at different temperatures. Explanations: $C$ cristobalite-like phase, $F$ feldspar, $F h$ ferrihydrite, $G$ goethite, $H$ hematite, $O l$ olivine, $Q$ quartz

spectrum of KOL sample heated at $150{ }^{\circ} \mathrm{C}$ shows virtually all the features of the unheated material, but at higher temperatures, distinct changes are evident (Fig. 3). Intensities of the bands related to $\mathrm{OH}$ vibrations (cca. 1635 and $3385 \mathrm{~cm}^{-1}$ ) as well as the intensity of the absorption band at $\sim 1400 \mathrm{~cm}^{-1}$, related to organic matter, are gradually reduced with the increasing temperature. At $200{ }^{\circ} \mathrm{C}$, diffraction peaks of goethite disappear partially (sample DM-1, Fig. 5) or completely (KOL, GD and DM-f samples, Figs. $4,6,7)$ and a broad $2.55 \AA$ ferrihydrite band is changing its shape. Nanocrystalline hematite develops at the same time, with some broad diffraction $110(2.52 \AA)$, $104(2.70 \AA), 300(1.45 \AA)$ and $021 \quad(3.69 \AA)$ peaks (Table 2) already recognizable. These peaks are not apparent in the XRD pattern of the GD sample (Fig. 6). This is consistent with FTIR spectrum, where strong band at $460 \mathrm{~cm}^{-1}$ is split into two peaks with the maxima at 540 


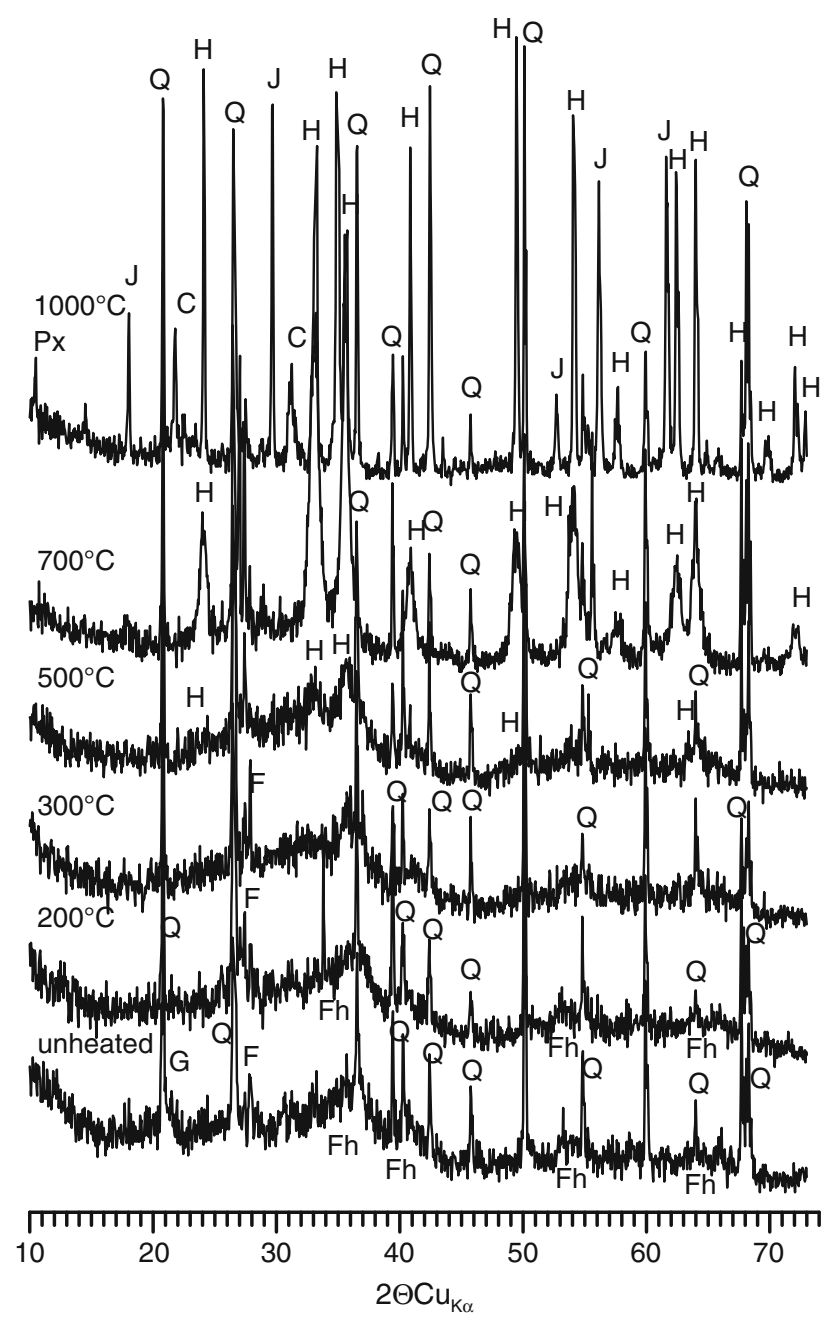

Fig. 6 XRD patterns of sample GD heated at different temperatures. Explanations: $C$ cristobalite-like phase, $F$ feldspar, $F h$ ferrihydrite, $G$ goethite, $H$ hematite, $J$ jacobsite-iwakiite, $P x$ pyroxene, $Q$ quartz

and $457 \mathrm{~cm}^{-1}$ (Fig. 3). These bands are attributed to the stretching $\mathrm{Fe}-\mathrm{O}$ vibrations in hematite [71]. Also, goethiterelated shoulders at $\sim 3240$ and $895 \mathrm{~cm}^{-1}$ disappear at $200{ }^{\circ} \mathrm{C}$. In the fine bog iron ores (KOL and DM-f) roasted to $200{ }^{\circ} \mathrm{C}$, an admixture of maghemite is also marked in XRD patterns (Figs. 4, 7). It is understandable, because maghemite is often recorded as a product of iron oxyhydroxide heating in the presence of organic matter $[1,11,72,73]$. Disappearance of goethite at $200{ }^{\circ} \mathrm{C}$, however, is quite surprising, since such temperature is several dozen of degrees lower than required for dehydroxylation [1, 74]. Only small changes in unit-cell dimensions of synthetic goethite heated at $200{ }^{\circ} \mathrm{C}$ were recorded in previous works [75], although goethite infrared emission spectra were markedly disturbed during heating to $175{ }^{\circ} \mathrm{C}$ [76]. The fade of the oxyhydroxide peaks can be an effect of decomposition of nanometer-sized crystallites, but decreasing crystallinity at the temperature just below
Fig. 7 XRD patterns of sample KOL heated at different temperatures. Explanations: $C$ cristobalite-like phase, $F$ feldspar, $G$ goethite, $H$ hematite, $M$ maghemite, $O l$ olivine, $Q$ quartz

that of dehydroxylation and conversion to hematite is also possible [77]. Ruan et al. [78] heated fine-crystalline synthetic goethite at $180-270{ }^{\circ} \mathrm{C}$ and detected hematite at $200{ }^{\circ} \mathrm{C}$ with no goethite observed above $230{ }^{\circ} \mathrm{C}$. Moreover, Walter et al. [79], on the basis of high-temperature XRD analysis, found a clear correlation between goethite particle size and transformation temperatures, and for very small particles, this process took place at temperature as low as $192{ }^{\circ} \mathrm{C}$. According to Christensen et al. [8], the conversion of nanocrystalline goethite into hematite could start at even lower temperatures-they detected first signs of transformation at $171{ }^{\circ} \mathrm{C}$. Therefore, goethite decomposition at relatively very low-temperature conditions could be at least partially related to its very fine crystallinity in bog iron ores. The other possible explanation of the process is that, as already mentioned, the fine bog iron ores contain significant amounts of the organic matter and its oxidation provides additional heat (see DTA curves of KOL and DM-f samples, Fig. 1), which may be sufficient to increase the sample temperature above that required for dehydroxylation. Although QMS signals of $\mathrm{H}_{2} \mathrm{O}$ and $\mathrm{CO}_{2}$ suggest that dehydroxylation precedes oxidation (Fig. 1), it should be noted that thermal analyses were performed in dynamic conditions (i.e., with constant heating rate) and the XRD patterns were recorded for the samples roasted in a furnace, thus in static conditions. Moreover, goethite peaks at $200{ }^{\circ} \mathrm{C}$ are recognizable only on the diffractogram of the DM-1 sample, which initially contained the least of the mineral (see Table 1, the highest $\mathrm{Fe}_{\mathrm{OX}} / \mathrm{Fe}_{\mathrm{DCB}}$ ratio of the sample indicates the lowest goethite to ferrihydrite proportion), but - at the same time- - which contained quite low amount of the organic matter (Table 1; Fig. 1). For comparison, the goethite is no more recognizable at $200{ }^{\circ} \mathrm{C}$ in the XRD pattern of the KOL sample, which was originally rich in the oxyhydroxide (Fig. 2) and the organic matter (Table 1; Fig. 1).

Transformation of ferrihydrite is an additional problem. As already mentioned, a shape modification of a wide diffraction band of the mineral is apparent, related to its gradual conversion into hematite. However, the complete transformation of ferrihydrite itself does not occur under such low-temperature conditions. The exotherm related to this process is usually noted at temperatures exceeding $300{ }^{\circ} \mathrm{C}[1]$ or, in case of the natural samples usually containing silicate admixtures, even at higher temperatures [10, 80-82]. Dry heating of ferrihydrite at $227^{\circ} \mathrm{C}$ resulted in evident changes of the XRD patterns recorded after $9 \mathrm{~h}$ of the process when approximately one quarter of the 


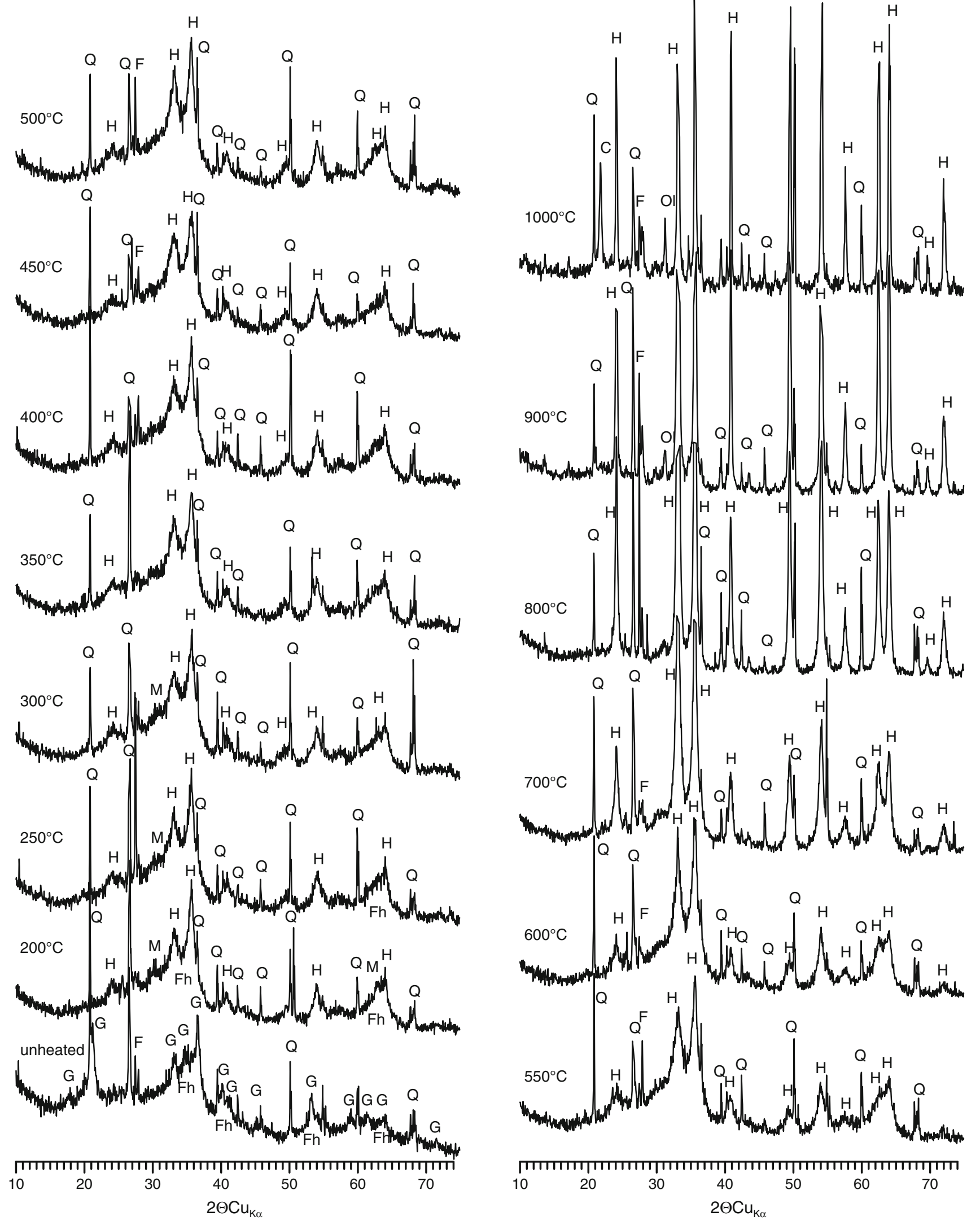


Table 2 Positions of main X-ray diffraction peaks $(\AA)$ of ferrihydrite, goethite, hematite and maghemite

\begin{tabular}{|c|c|c|c|c|c|c|c|c|c|c|c|}
\hline \multicolumn{3}{|c|}{ Ferrihydrite (29-712) } & \multicolumn{3}{|c|}{ Goethite (29-713) } & \multicolumn{3}{|c|}{ Hematite (15-534) } & \multicolumn{3}{|c|}{ Maghemite (25-1402) } \\
\hline$d$ & $I$ & hkl & $d$ & $I$ & hkl & $d$ & $I$ & hkl & $d$ & $I$ & hkl \\
\hline 2.50 & 100 & 100 & 4.98 & 12 & 020 & 3.66 & 25 & 012 & 2.95 & 30 & 220 \\
\hline 2.21 & 80 & 112 & 4.183 & 100 & 110 & 2.69 & 100 & 104 & 2.514 & 100 & 313 \\
\hline 1.96 & 80 & 113 & 3.383 & 10 & 120 & 2.51 & 50 & 110 & 2.086 & 15 & 400 \\
\hline 1.72 & 50 & 114 & 2.693 & 35 & 130 & 2.201 & 30 & 113 & 1.604 & 20 & 513 \\
\hline 1.51 & 70 & 115 & 2.583 & 12 & 021 & 1.838 & 40 & 024 & 1.474 & 40 & 440 \\
\hline \multirow[t]{6}{*}{1.48} & 80 & 300 & 2.489 & 10 & 040 & 1.690 & 60 & 116 & & & \\
\hline & & & 2.450 & 50 & 111 & 1.596 & 16 & 018 & & & \\
\hline & & & 2.253 & 14 & 121 & 1.484 & 35 & 214 & & & \\
\hline & & & 2.190 & 18 & 140 & 1.452 & 35 & 300 & & & \\
\hline & & & 1.7192 & 20 & 221 & 1.310 & 20 & $10 \underline{10}$ & & & \\
\hline & & & 1.5637 & 10 & 151 & & & & & & \\
\hline
\end{tabular}

Less-intense peaks $(I<10)$ have been omitted. Numbers in brackets denote ICDD cards

oxyhydroxide was converted to hematite $[1,83]$. On the other hand, even at temperatures much lower than $200{ }^{\circ} \mathrm{C}$, some changes in the composition and surface chemistry of the oxyhydroxide may occur. Prolonged heating at $>100{ }^{\circ} \mathrm{C}$ causes ferrihydrite $(6 \mathrm{~L})$ dehydration and reduction of the specific surface area $[59,83]$. Under favorable conditions, an intermediate phase between ferrihydrite and hematite may form [84]. In the case of the bog iron ores, given the relatively short $(1 \mathrm{~h})$ time of roasting, a partially dehydrated ferrihydrite probably occurs at $200{ }^{\circ} \mathrm{C}$. Ferrihydrite thermal reactions were not observed directly during STA analysis because it is virtually impossible in such a complex material as bog iron ore. The oxyhydroxide continuously loses water, and for this reason, dehydroxylation endotherm is not visible [1]. Moreover, the exotherm related to the transformation to hematite is located in the temperature region in which organic matter is decomposed; hence, the exotherm of organic matter oxidation is apparent instead. In order to prevent organic matter oxidation, thermal analysis could be carried out in an inert atmosphere (e.g., in $\mathrm{N}_{2}$ ). However, in such conditions, the ferrihydrite exotherm is usually absent [1]. In bog iron ores that exotherm was observed only in cases, in which, prior to the analysis, samples had been treated with concentrated $\mathrm{H}_{2} \mathrm{O}_{2}$ in order to remove organic matter [54]. Such a treatment, however, removes manganese oxides as well, and therefore, it was not applied in this work.

Goethite disappears in all the samples at temperatures of $300{ }^{\circ} \mathrm{C}$ (Figs. 4-7), which is consistent with literature datadehydroxylation endotherm of the oxyhydroxide usually occurs between 250 and $300^{\circ} \mathrm{C}[1,3,6,14,75,85,86]$. The hematite 110,104 and 116 peaks are distinct in the XRD patterns, except the GD sample (Fig. 6). This may be partly related to overlapping effect of quartz, although an influence of high manganese content in the sample is feasible as well. The majority of the manganese is bound in Mn oxides; however, selective chemical extractions and SEM-EDS analyses indicated that substantial amount of the metal in the Mn-rich bog iron ores could be embedded in the goethite structure [54]. The results of thermal analyses indirectly support this possibility. Isomorphic substitution of $\mathrm{Mn}$ for $\mathrm{Fe}$ in goethite complicates the progress of dehydroxylation [3, 14, 87], which can cause the formation of fully developed hematite at a temperature somewhat higher than during transformation of pure (non-substituted) goethite, despite the Mn-goethite itself starts to dehydroxylate at slightly lower temperature than the pure one.

There is no clear difference between XRD patterns of the bog iron ores heated at 300 and $500{ }^{\circ} \mathrm{C}$, except the GD sample, where a broad 104 hematite peak appears at $500{ }^{\circ} \mathrm{C}$ (Fig. 6). The complete oxidation of organic matter is evidenced by disappearance of the absorption band at $1400 \mathrm{~cm}^{-1}$ in FTIR spectra collected after annealing bog iron ore above $400{ }^{\circ} \mathrm{C}$ (Fig. 3). This is in a good agreement with the results of thermal analysis. Interestingly, the FWHM (full widths at half maxima) values of hematite peaks measured for KOL sample slightly increase in the range of $200-450{ }^{\circ} \mathrm{C}$ (Fig. 8), suggesting some decrease in crystallinity and/or structural ordering of the oxide in this temperature range. Moreover, the intensity ratios of both 104-113 and 024-113 peaks, very sensitive to the incorporation of hydroxyl groups in the hematite structure [3], are very low (Fig. 8). This is consistent with a general observation that in hematite formed by goethite dehydroxylation, hydroxyls are trapped and the oxide can retain up to half the stoichiometric water content of the parent oxyhydroxide, giving a formula $\mathrm{Fe}_{2-\mathrm{x}-/ 3}(\mathrm{OH})_{\mathrm{x}} \mathrm{O}_{3-\mathrm{x}}[88,89]$. Therefore, the "hydrated" product of goethite conversion in 


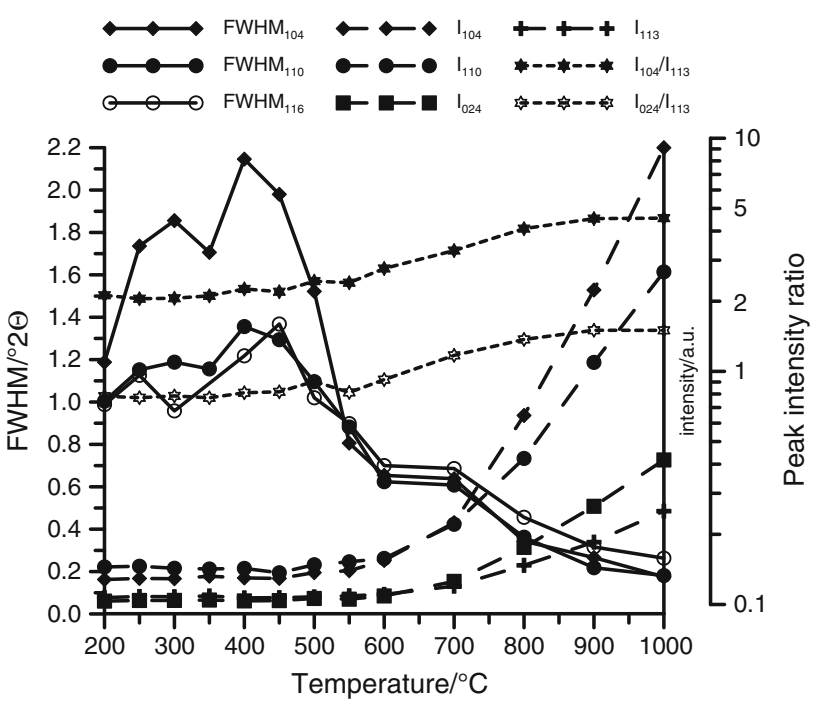

Fig. 8 Full widths at half maxima (FWHM, solid lines), intensities (I, dashed lines) and intensity ratios (tightly dashed lines) of selected hematite XRD peaks (data for KOL sample only)

the bog iron ores could be called protohematite [75]. FTIR spectra provide additional data supporting this supposition. As already mentioned, the intensities of the bands related to $\mathrm{OH}$ vibrations (cca. 1635 and $3385 \mathrm{~cm}^{-1}$ ) are gradually reduced with the increasing temperature (Fig. 3), but these features are recognizable even for the sample roasted at $800 \mathrm{~cm}^{-1}$. Some water could be, of course, physically adsorbed from the air after annealing and prior to analysis, but all the samples were handled identically. Hence, some hydroxyl groups probably remain in the structure of annealing products [i.e., in (proto)hematite], at least at $500{ }^{\circ} \mathrm{C}$. The peak at cca. $3385 \mathrm{~cm}^{-1}$ is located in nearly the same position for the samples roasted at lower temperatures $\left(<300{ }^{\circ} \mathrm{C}\right)$ and is gradually slightly shifted to higher wave numbers (up to ca. $3460 \mathrm{~cm}^{-1}$ ) with the increase in the heating temperature (Fig. 3). Such a shift could indicate a reduction in bond strength [90]. As a measure of hematite crystallinity, so-called resolution function, i.e., the ratio of the sum of the $\sim 540$ and $\sim 460 \mathrm{~cm}^{-1}$ peak absorbances to the absorbance of the minimum between the peaks, was proposed by Sawaby et al. [91]. The values calculated for the KOL sample annealed at $200-500{ }^{\circ} \mathrm{C}$ range from 2.1 to 2.2 and are almost the same as measured [91] for poorly crystalline protohematites obtained by roasting of goethiterich iron ore. The oxide lattice disorder is evidenced by distinct broadening of the above-mentioned bands [71].

Above $500{ }^{\circ} \mathrm{C}$, all the XRD patterns (Figs. 4-7) show almost linear increase in the hematite peaks intensities and a decrease in their FWHM (Fig. 8), thus an increase in the oxide crystallinity. At $700{ }^{\circ} \mathrm{C}$, two additional hematite peaks 018 and 1010 appear and a clear separation of 300 and 214 peaks (Table 2) becomes visible (Figs. 4-7). A strong 104 peak, which was less intensive than 110 peak at lower temperatures, gets to be a dominating feature of XRD patterns (Fig. 8). However, $\mathrm{I}_{104} / \mathrm{I}_{113}$ and $\mathrm{I}_{024} / \mathrm{I}_{113}$ ratios are still much lower than theoretical values, which for hematite sensu stricto equal to 5 and 2, respectively [3]. This observation suggests that at $700{ }^{\circ} \mathrm{C}$, protohematite still exists, being consistent with Gualtieri and Venturelli finding [75] that the conversion of protohematite to fully developed hematite takes place at $800{ }^{\circ} \mathrm{C}$. Several works [e.g., 92, 93] showed that this transformation could start at even higher temperature, above $900{ }^{\circ} \mathrm{C}$.

In the XRD patterns of the samples heated at $1000{ }^{\circ} \mathrm{C}$, a series of sharp hematite peaks: 3.66, 2.69, 2.51, 2.20, 1.84, $1.69,1.596,1.484,1.452$ and $1.310 \AA$ is apparent (Figs. 4-7; Table 2). The intensity $\mathrm{I}_{104} / \mathrm{I}_{113}$ and $\mathrm{I}_{024} / \mathrm{I}_{113}$ ratios increase up to 4.2-4.8 and 1.5, respectively (Fig. 8), so ones much closer to the model values. They are lower only in the GD sample, matching ca. 4 and 1.3 (Fig. 8). The increase in hematite crystallinity in higher temperatures is evidenced by FTIR spectra as well-at $\geq 700{ }^{\circ} \mathrm{C}$, splitting of the lowwave numbers bands $\left(\sim 457\right.$ and $\left.540 \mathrm{~cm}^{-1}\right)$ is getting more apparent, and the bands themselves are getting sharper. A slight shift of the latter peak toward higher wave numbers is visible, which is again a sign of increasing crystallinity [65]. Also, the "resolution functions" calculated for the highest temperatures of annealing amount to cca. 3, i.e., the value typical for crystalline hematite [91]. In the GD Mn-rich bog iron ore, the presence of manganous spinels of the jacobsite-iwakiite $\left(\mathrm{MnFe}_{2} \mathrm{O}_{4}\right)$ type is evident in the XRD pattern (Fig. 6). Reduction of $\mathrm{Mn}^{4+}$ to $\mathrm{Mn}^{3+}\left(\right.$ and $\mathrm{Mn}^{2+}$ ), recorded in the thermal pattern of the sample (Fig. 1), promoted formation of these manganous spinels. The transformation might take place according to the following solid-state reaction [94]:

$\mathrm{Mn}_{2} \mathrm{O}_{3}+2 \mathrm{Fe}_{2} \mathrm{O}_{3} \rightarrow 2 \mathrm{MnFe}_{2} \mathrm{O}_{4}+1 / 2 \mathrm{O}_{2}$

Such oxides are often found in the products of manganese ores agglomeration [95]. Additional peak at $4.1 \AA$, present in the XRD patterns of all the samples, indicates that a cristobalite-type silica phase emerged as well, resulting from $\mathrm{Si}$ admixture in ferrihydrite, which is a common feature of the oxyhydroxide found in the nature $[1,10,80]$. A portion of the element probably enters hematite structure during ferrihydrite thermal transformation, but is expelled at higher temperatures $[10,60,82]$. The absorption band at $1080 \mathrm{~cm}^{-1}$ arising in FTIR spectrum of the KOL sample annealed at $700{ }^{\circ} \mathrm{C}$ (Fig. 3) suggests that the cristobalite formation starts at this temperature. However, the full development of the $\mathrm{SiO}_{2}$ polymorph finishes at $1000{ }^{\circ} \mathrm{C}$-in the relevant FTIR spectrum, additional cristobalite bands [65] appear at cca. 
1200 (shoulder), 1140 (shoulder) and $795 \mathrm{~cm}^{-1}$ (Fig. 3). The presence of cristobalite was recently reported in heated ferruginous (goethite, schwertmannite and ferrihydrite) AMD precipitates, but it was interpreted as related to amorphous silica content in untreated sample [16]. This is hardly the case of bog iron ores, although electron microscopic observations showed traces of opal-type silica in some samples (but not in these four samples studied here). The majority of non-siliciclastic $\mathrm{Si}$ is bound in ferrihydrite which is evidenced by [54]: (1) the results of selective chemical extractions (in acid ammonium oxalate extracts, $\mathrm{Si}$ was present and the reagent dissolves ferrihydrite but does not dissolve amorphous silica), (2) the results of EDS analyses of ferrihydrite aggregates (all these aggregates contained significant amounts of $\mathrm{Si}$ ) and (3) FTIR spectra, which did not reveal the presence of amorphous silica in unheated KOL sample (Fig. 3).

Diffractograms of the samples DM-f and KOL reveal small peaks at 2.86 and $2.64 \AA$, suggesting that at $1000{ }^{\circ} \mathrm{C}$, ferrous olivines with fayalite structure emerged. Fayalite and Ca-fayalite are widespread in the iron ore sinters [96-98]. The presence of olivines might explain the arising of FTIR shoulders at 940,970 and $997 \mathrm{~cm}^{-1}[65,66]$.

Origin of some peaks which are recognizable on XRD patterns of the samples heated at $1000{ }^{\circ} \mathrm{C}$, namely $\sim 7.2$, 6.5-6.6 and 3.55 ̊ (samples DM-f and DM-1, Figs. 4, 5) and $8.2 \AA$ (sample GD, Fig. 6), remains unclear. They probably reflect the presence of poorly defined ferric phosphates, secondary pyroxenes and/or calcium-aluminum silicates. Pyroxenes were already found in roasted at $800{ }^{\circ} \mathrm{C} \mathrm{Si}$-ferrihydrites precipitated from the submarine hydrothermal fluids [99]. Pyroxene and calcium silicates are also common in metallurgical sinters [95, 98].

\section{Specific surface area and porosity}

Bog iron ores exhibit large surface areas, occasionally exceeding a value of $200 \mathrm{~m}^{2} \mathrm{~g}^{-1}$ [24]. Table 3 summarizes changes of specific surface area and porosity of the fine bog iron ore from Kolechowice (sample KOL) in the course of roasting. During heating at $200{ }^{\circ} \mathrm{C}$, the surface area slightly decreased (about $10 \%$ ) from initial 152 to $139 \mathrm{~m}^{2} \mathrm{~g}^{-1}$ (Table 3). Total porosity and macropore proportion increased, with simultaneous decrease in the volume and proportion of micropores (Fig. 9). This is probably an effect of both structural changes and mineral transformations. Initial development of microporosity due to the expulsion of water from iron oxyhydroxides is usually followed by the coalescence of the micropores [1]. In the case of bog iron ore, dehydroxylation starts below $200{ }^{\circ} \mathrm{C}$, which is evidenced by the disappearance of goethite XRD peaks and infrared absorption bands. Hence, the coalescence of micropores and shrinkage of nanocrystalline aggregates produce meso- and macroporosity. Also, the stress associated with water expulsion may cause the development of cracks propagated from the surfaces of particles [15]. Dehydroxylation and decomposition of goethite and ferrihydrite are followed by hematite formation. As goethite-hematite conversion is a topotactic reaction $[86,100,101]$, hematite obtained at relatively low temperatures should retain size and morphology of the precursor $[1,102]$, and for that reason, surface area has not decreased significantly. The growth of hematite crystallites via surface diffusion-coalescence mechanism probably promoted the conversion of micropores into mesopores $[1,100]$, which is reflected by the volume increase in the latter. At $400{ }^{\circ} \mathrm{C}$, a small increase in the surface area (up to $143 \mathrm{~m}^{2} \mathrm{~g}^{-1}$ ) and total porosity (to $0.276 \mathrm{~cm}^{3} \mathrm{~g}^{-1}$ ) was recorded, with the proportion of all kinds of pores appeared to remain roughly the same (Table 3; Fig. 9). This is in agreement with a slight broadening of the hematite peaks (Fig. 8), and similar changes observed previously in hematite formed by goethite heating [86, 103]. The removal of organic matter is probably important as well, because their molecules were found to block the access of gases to the pores and consequently to lower specific

Table 3 Porous texture parameters of natural and roasted bog iron ore (sample KOL)

\begin{tabular}{|c|c|c|c|c|c|c|}
\hline & Unheated & $200^{\circ} \mathrm{C}$ & $400^{\circ} \mathrm{C}^{\mathrm{a}}$ & $400^{\circ} \mathrm{C}^{\mathrm{b}}$ & $700^{\circ} \mathrm{C}$ & $1000^{\circ} \mathrm{C}$ \\
\hline Surface area, $S_{\mathrm{BET}} / \mathrm{m}^{2} \mathrm{~g}^{-1}$ & 152 & 139 & 67 & 143 & 78 & 2.56 \\
\hline Total pore volume, $V_{\mathrm{t}} / \mathrm{cm}^{3} \mathrm{~g}^{-1}$ & 0.190 & 0.257 & 0.194 & 0.276 & 0.191 & 0.015 \\
\hline Micropore volume, $V_{\mathrm{mic}} / \mathrm{cm}^{3} \mathrm{~g}^{-1}$ & 0.063 & 0.051 & 0.026 & 0.053 & 0.029 & 0.001 \\
\hline Micropore proportion, $V_{\mathrm{mic}} / V_{\mathrm{t}}$ & 0.332 & 0.198 & 0.134 & 0.192 & 0.152 & 0.067 \\
\hline Mesopore volume, $V_{\text {mes }} / \mathrm{cm}^{3} \mathrm{~g}^{-1}$ & 0.095 & 0.158 & 0.106 & 0.169 & 0.150 & 0.006 \\
\hline Mesopore proportion, $V_{\text {mes }} / V_{\mathrm{t}}$ & 0.500 & 0.615 & 0.546 & 0.612 & 0.785 & 0.400 \\
\hline Macropore volume, $V_{\mathrm{mac}} / \mathrm{cm}^{3} \mathrm{~g}^{-1}$ & 0.032 & 0.048 & 0.062 & 0.054 & 0.012 & 0.008 \\
\hline Macropore proportion, $V_{\mathrm{mac}} / V_{\mathrm{t}}$ & 0.168 & 0.187 & 0.320 & 0.196 & 0.063 & 0.533 \\
\hline
\end{tabular}

a, b Sample roasted with insufficient and full access of air, respectively 
Fig. 9 Porous texture parameters of natural and roasted KOL sample. Explanations: $B E T$ specific surface area (dashed line), $V_{T O T}$ total pore volume, $V_{M I C}$ micropore volume, $V_{M E S}$ mesopore volume, $V_{M A C}$ macropore volume. Pore volumes are plotted with solid lines and pore proportions with tightly dashed lines
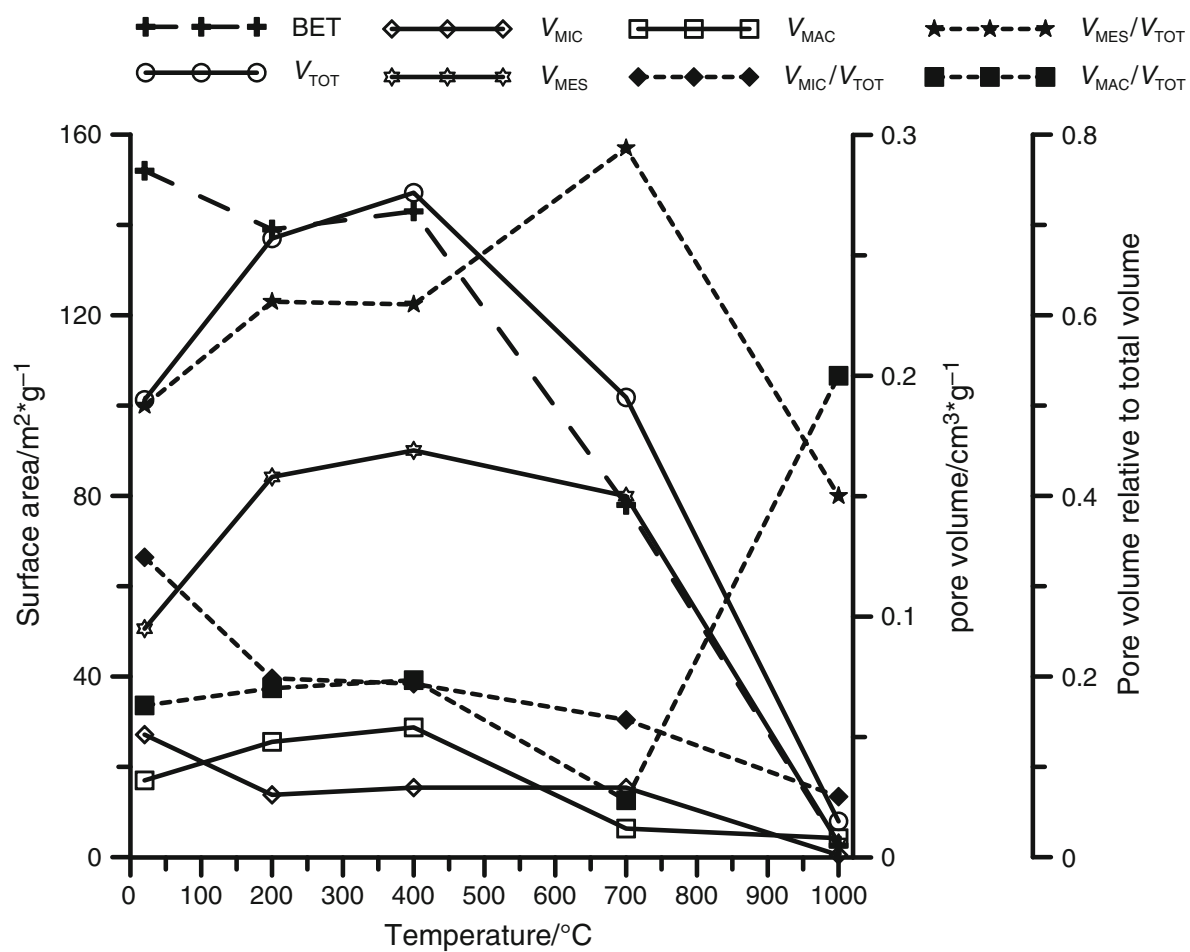

surface area [51]. This is consistent with the disappearance of organic-matter-related FTIR $\sim 1400 \mathrm{~cm}^{-1}$ band at $400{ }^{\circ} \mathrm{C}$ (Fig. 3). Admittedly, the exotherm originated from the oxidation of the organic matter and accompanying mass loss recorded on DTA and TG/DTG curves, respectively, ends in temperatures higher than $400{ }^{\circ} \mathrm{C}$ (Fig. 1). It has to be noted, however, that the thermal analysis was carried out in a dynamic mode with the sample heated at a constant rate, which obviously shifts the reactions associated with mass changes to higher temperatures.

It should also be noted that if the roasting is run under conditions of insufficient access of air, a sudden decrease in specific surface area and total porosity together with a distinct increase in macropore proportion is observed [column $400{ }^{\circ} \mathrm{C}(\mathrm{a})$ in Table 3]. This is an effect of maghemite formation beside hematite.

Together with heating and further increase in temperature, a significant decrease in specific surface area occurs (Fig. 9), reaching values of $78 \mathrm{~m}^{2} \mathrm{~g}^{-1}$ at $700{ }^{\circ} \mathrm{C}$ and even $2.5 \mathrm{~m}^{2} \mathrm{~g}^{-1}$ at $1000{ }^{\circ} \mathrm{C}$ (Table 3). These are consistent with the increase in hematite crystallinity and average crystallite dimensions inferred from XRD data (Figs. 4-8). This is the result of the aggregation of small hematite crystallites into larger ones and sintering [1,60]. Total porosity is diminished a dozen times, and micropore volume decreases to almost zero value at the same time, with subsequent increase in the proportions of both mesopores and macropores (Table 3). Similar changes were observed during thermal transformation of goethite to hematite [86].

\section{Summary and conclusions}

Our study showed that a series of chemical reactions and physical transformations occur during heating of the bog iron ores under oxidizing conditions. At lower temperature, physically adsorbed surface water is removed followed by the continuous release of structural water and hydroxyls from ferrihydrite. A further increase in heating temperature results in dehydration and dehydroxylation of iron oxyhydroxides as well as oxidation of organic matter. These slightly affect the specific surface area but lower volume of micropores. During heating of bog iron ore rich in organic matter, iron oxyhydroxides may dehydroxylate at lower temperatures. Also, maghemite may form as an intermediate product, particularly during the heating with insufficient air access. Such case with maghemite formed is accompanied with a distinct decrease in surface area and microporosity. Dehydroxylation and oxidation processes terminate in the temperature range of $400-600{ }^{\circ} \mathrm{C}$, with nanocrystalline hematite as the main product. The hematite presumably contains hydroxyl groups (and other impurities, like silicate and phosphate) and therefore can be named protohematite. Protohematite undergoes recrystallization to the proper (stoichiometric) hematite at $800{ }^{\circ} \mathrm{C}$, which is probably associated with the removal of $\mathrm{OH}$ groups and silica. The latter forms a separate cristobalitelike phase. Manganese oxides in the Mn-rich bog iron ores are partially reduced and then converted to jacobsite-like spinels. At the highest temperatures of roasting, various 
secondary silicates can be encountered as well. The transformations occurring at high temperature lead to a drastic fall of a specific surface area and to the destruction of porous texture of the bog iron ores.

This work documents that the heating of bog iron ores, even at relatively high temperatures of $400-450{ }^{\circ} \mathrm{C}$, has not resulted in pronounced reduction of the surface area and porosity, despite distinct changes of mineral composition. This may be of importance if the utilization of bog iron ores is considered, because a relatively simple treatment (roasting) results in the modification of the material composition, while the porous texture parameters remain relatively weakly affected.

The transformations of iron oxyhydroxides in bog iron ores occur at temperatures different than those reported for pure compounds wherein the differences concern the shifts toward both higher and lower temperatures. From the viewpoint of the raw material utilization (as a sorbent for instance), it is obviously disadvantageous feature; however, it allows (through extended product analysis) inferring the composition and properties of the starting material and/or the conditions to which the material (the bog iron ore) was subjected to. It might be interesting, e.g., in archeology, in due course of deducing of the details of iron ore dressing processes (the roasting was the simplest and at the same time the most effective way of ore processing prior to bloomery process in the past) or inferring the methods of processing, which were applied in the past to natural ferruginous pigments in order to achieve the desired color effect.

Acknowledgements This work was supported by LIDER Project No. LIDER/043/403/L-4/12/NCBR/2013 from The National Centre for Research and Development, Poland. The authors are indebted to Anna Tomczyk M.Sc. for her help during analysis and interpretation of porous texture parameters. Dr. Bartosz Budzyń is acknowledged for carefully reading the manuscript. We also thank two anonymous reviewers whose constructive comments and remarks allowed improving the quality and clarity of the manuscript.

Open Access This article is distributed under the terms of the Creative Commons Attribution 4.0 International License (http://crea tivecommons.org/licenses/by/4.0/), which permits unrestricted use, distribution, and reproduction in any medium, provided you give appropriate credit to the original author(s) and the source, provide a link to the Creative Commons license, and indicate if changes were made.

\section{References}

1. Cornell RM, Schwertmann U. The iron oxides: structure, properties, reactions, occurrences and uses. 2nd ed. Weinheim: Wiley; 2003.

2. Murad E, Schwertmann U. Temporal stability of a fine-grained magnetite. Clays Clay Miner. 1993;41:111-3.

3. Wells MA, Fitzpatrick RW, Gilkes RJ. Thermal and mineral properties of $\mathrm{Al}-, \mathrm{Cr}-, \mathrm{Mn}-, \mathrm{Ni}-$ and Ti-substituted goethite. Clays Clay Miner. 2006;54:176-94.
4. Šubrt J, Balek V, Criado JM, Pérez-Maqueda LA, Večernikova E. Characterisation of $\alpha-\mathrm{FeOOH}$ grinding products using simultaneous DTA and TG/DTG coupled with MS. J Therm Anal. 1998;53:509-17.

5. Dinesen AR, Pedersen CT, Bender Koch C. The thermal conversion of lepidocrocite $(\gamma-\mathrm{FeOOH})$ revisited. J Therm Anal Calorim. 2001;64:1303-10.

6. Mitov I, Paneva D, Kunev B. Comparative study of the thermal decomposition of iron oxyhydroxides. Thermochim Acta. 2002;386:179-88.

7. Przepiera K, Przepiera A. Thermal transformations of selected transition metals hydroxides. J Therm Anal Calorim. 2003;74: 659-66.

8. Christensen AN, Jensen TR, Bahl CRH, DiMasi E. Nano size crystals of goethite, $\alpha-\mathrm{FeOOH}$. Synthesis and thermal transformation. J Solid State Chem. 2007;180:1431-5.

9. Liu H, Chen T, Xie Q, Zou X, Qing C, Frost RL. Kinetic study of goethite dehydration and the effect of aluminum substitution on the dehydrate. Thermochim Acta. 2012;545:20-5.

10. Pieczara G, Rzepa G, Gaweł A. The influence of silicate content on thermal stability of 2-line ferrihydrite and properties of its transformation products. Geol Geophys Environ. 2014;40:160-1.

11. Perrier N, Gilkes RJ, Colin F. Heating Fe oxide-rich soils increases the dissolution rate of metals. Clays Clay Miner. 2006;52:165-75.

12. Morcos RM, Navrotsky A. Iron ore sintering. Characterization by calorimetry and thermal analysis. $\mathrm{J}$ Therm Anal Calorim. 2009;96:353-61.

13. Zevgolis EN, Zografdis C, Perraki T, Devlin E. Phase transformations of nickeliferous laterites during preheating and reduction with carbon monoxide. $\mathrm{J}$ Therm Anal Calorim. 2010;100:133-9.

14. Strezov V, Ziolkowski A, Evans TJ, Nelson PF. Assessment of evolution of loss on ignition matter during heating of iron ores. J Therm Anal Calorim. 2010;100:901-7.

15. Strezov V, Evans TJ, Zymla V, Strezov L. Structural deterioration of iron ore particles during thermal processing. Int $\mathbf{J}$ Miner Process. 2011;100:27-32.

16. Pulišová $\mathrm{P}$, Máša $\mathrm{B}$, Michalková $\mathrm{E}$, Večerniková $\mathrm{E}$, Mařiková M, Bezdička P, Murafa N, Šubrt J. Thermal behaviour of natural and synthetic iron precipitates from mine drainage. $\mathrm{J}$ Therm Anal Calorim. 2014;116:625-32.

17. Wang Y, Xing S, Zhang Y, Li Z, Ma Y, Zhang Z. Mineralogical and thermal characteristics of low-grade Jinlong bauxite sourced from Guangxi Province, China. J Therm Anal Calorim. 2015. doi:10.1007/s10973-015-4742-6.

18. Živković D, Štrbac N, Sokić M, Andrić V, Jovanović I, Jovičić M, Andjelić B, Radoslavlejić S. Physicochemical investigation of some archaeometallurgical findings from locality Kmpije (Bor, Serbia). J Therm Anal Calorim. 2014;118:1369-73.

19. Ion RM, Radovici C, Fierascu RC, Fierascu I. Thermal and mineralogical investigations of iron archaeological materials. J Therm Anal Calorim. 2015. doi:10.1007/s10973-015-4659-0.

20. Atasoy A. The comparison of the Bayer process wastes on the base of chemical and physical properties. J Therm Anal Calorim. 2007;90:153-8.

21. Pascual J, Corpas FA, López-Beceiro J, Benítez-Guerrero M, Artiaga R. Thermal characterization of a Spanish red mud. J Therm Anal Calorim. 2009;96:407-12.

22. Rivas Mercury JM, Cabral AA, Paiva AEM, Angélica RS, Neves RF, Scheller T. Thermal behavior and evolution of the minerals of Brazilian red mud. $\mathrm{J}$ Therm Anal Calorim. 2011;2011(104):635-43.

23. Banning A. Bog iron ores and their potential role in arsenic dynamics: an overview and "Paleo Example". Eng Life Sci. 2008;8:641-9. 
24. Ratajczak T, Rzepa G. Polish bog iron ores. Kraków: Wyd. AGH; 2011 (in Polish).

25. Ramanaidou ER, Wells MA. Sedimentary hosted iron ores. In: Holland HD, Turekian KK, editors. Treatise on geochemistry. 2nd ed. Oxford: Elsevier; 2014. p. 313-55.

26. Crerar DA, Knox GW, Means JL. Biogeochemistry of bog iron in the New Jersey pine barrens. Chem Geol. 1979;24:111-35.

27. De Geyter G, Vandenberghe Verdonck L, Stoops G. Mineralogy of Holocene bog-iron ore from northern Belgium. N Jb Mineral Abh. 1985;153:1-17.

28. Joosten I, Jansen JBH, Kars H. Geochemistry and the past: estimation of the output of a Germanic iron production site in the Netherlands. J Geochem Explor. 1998;62:129-37.

29. Breuning-Madsen H, Rønsbo J, Holst MK. Comparison of the composition of iron pans in Danish burial mounds with bog iron and spodic material. Catena. 2000;39:1-9.

30. Bricker OP, Newell WL, Simon NS. Bog iron formation in the Nassawango watershed, Maryland. U.S. Geological Survey Open-File Report 03-346, 2003.

31. Kaczorek D, Sommer M. Micromorphology, chemistry and mineralogy of bog iron ores from Poland. Catena. 2003;54:392-402.

32. Kaczorek D, Sommer M, Andruschkewitsch I, Oktaba L, Czerwiński Z, Stahr K. A comparative micromorphological and chemical study of "Raseneisenstein" (bog iron ore) and "Ortstein". Geoderma. 2004;121:83-94.

33. Kholodov VN, Nedumov RI, Golubovskaya EV. Facies types of sedimentary iron ore deposits and their geochemical features: communication 1: Facies groups of sedimentary ores, their lithology, and genesis. Lithol Miner Resour. 2012;47:447-72.

34. Piwocki M. Mineral raw materials and commodities of Poland. Prz Geol. 2004;52:744-52.

35. Mighall TM, Foster IDL, Crew P, Chapman AS, Finn A. Using mineral magnetism to characterise ironworking and to detect its evidence in peat bogs. J Arch Sci. 2009;36:130-9.

36. Török B, Thiele A. Extracting phosphoric iron under laboratorial conditions smelting bog iron ores. IOP Conf Series Mater Sci Eng. 2013. doi:10.1088/1757-899X/47/1/012034.

37. Virtanen K. Geological control of iron and phosphorous precipitates in mires of the Ruukki-Vihanti area, Central Finland. Bull Geol Surv Finl. 1994;375:1-69.

38. Kraczkowska I, Ratajczak T, Rzepa G. Mineral composition and physico-mechanical properties of the lump bog iron ores used in historical buildings in Poland. Prz Geol. 2001;49:1147-56.

39. Dreesen R, Dusar M. Historical building stones in the province of Limburg (NE Belgium): role of petrography in the provenance and durability assessment. Mater Character. 2004;53: 273-87.

40. Bärbel A. Verwitterung und Konservierung von Objekten aus Raseneisenstein. Z Dtsch Ges Geowiss. 2005;156:151-8.

41. Więckowska J. Catalytic and adsorptive desulphurization of gases. Catal Today. 1995;24:405-65.

42. Schweigkofler M, Niessner R. Removal of siloxanes in biogases. J Hazard Mater. 2001;B83:183-96.

43. Gaj K, Cybulska H, Knop F, Steininger M. Examination of biogas hydrogen sulphide sorption on a layer of activated bog ore. Environ Protect Eng. 2008;34:33-41.

44. Gaj K, Cybulska-Szulc H. Time changeability model of the bog ore sorption ability. Ecol Chem Eng S. 2014;21:113-23.

45. Zdeb M. An efficiency of $\mathrm{H}_{2} \mathrm{~S}$ removal from biogas via physicochemical and biological methods-a case study. Ann Set Environ Prot. 2013;15:551-63.

46. Rzepa G, Ratajczak T. Mineral composition of bog iron ores and their sorption properties. Miner Resour Manag. 2004;20:61-73 (in Polish with English summary).

47. Rzepa G, Bajda T, Ratajczak T. Utilization of bog iron ores as sorbents of heavy metals. J Hazard Mater. 2009;162:1007-13.
48. Stoops G. SEM and light microscopic observations of minerals in bog ores of the Belgian Campine. Geoderma. 1983;30: $179-86$.

49. Jakobsen BH. Accumulation of pyrite and Fe-rich carbonate and phosphate minerals in a lowland moor area. J Soil Sci. 1988;39:447-55.

50. Bajda T, Klojzy-Karczmarczyk B, Rzepa G, Fijał J, Mazurek J. Sorption of $\mathrm{Cu}(\mathrm{II}), \mathrm{Zn}$ (II) and $\mathrm{Hg}$ (II) onto natural and modified bog iron ores. Miner Resour Manag. 2004;20:83-98 (in Polish with English summary).

51. Fijał J, Ziętkiewicz J. Influence of the way of bog iron ores modification on their sorptive properties. Miner Resour Manag. 2004;20:75-81 (in Polish with English summary).

52. Schwertmann U, Schulze DG, Murad E. Identification of ferrihydrite in soils by dissolution kinetics, differential X-Ray diffraction and Mössbauer spectroscopy. Soil Sci Soc Am J. 1982;46:869-75.

53. Rzepa G, Bajda T, Sikora M. Speciation and concentration of trace elements in the ferruginous sediments of Poland. Pol J Environ Stud. 2006;15:474-8.

54. Rzepa G. Mineral and chemical composition of bog iron ores and their physicochemical properties in terms of the possibility of using them as natural sorbents. Ph.D. thesis, AGH; Kraków; 2003. (in Polish).

55. Sandell EB. Micro determination of water by the Penfield method. Mikrochem ver Microchim Acta. 1951;38:487-91.

56. Mehra OP, Jackson ML. Iron oxide removal from soils and clays by a dithionite-citrate system buffered with sodium carbonate. Clays Clay Miner. 1960;7:317-27.

57. The Powder Diffraction File PDF- $4^{+}$. International Centre for Diffraction Data, Newton Square, 2013.

58. Brunauer S, Emmett PH, Teller E. Adsorption of gases in multimolecular layers. J Am Chem Soc. 1938;60:309-19.

59. Weidler PG. BET sample pretreatment of synthetic ferrihydrite and its influence on the determination of surface area and porosity. J Porous Mater. 1997;4:165-9.

60. Glasauer SM, Hug P, Weidler PG, Gehring AU. Inhibition of sintering by $\mathrm{Si}$ during the conversion of Si-rich ferrihydrite to hematite. Clays Clay Miner. 2000;48:51-6.

61. González C, Gutiérrez JI, González-Velasco JR, Cid A, Arranz A, Arranz JF. Transformations of manganese oxides under different thermal conditions. J Therm Anal. 1996;47:93-102.

62. Földvári M. Handbook of thermogravimetric system of minerals and its use in geological practice. Budapest: Occasional Papers of the Geological Institute of Hungary, 213; 2011.

63. Liptay G. Atlas of thermoanalytical curves (TG-, DTG-, DTAcurves measured simultaneously), vol. 2. Budapest: Akadémiai Kiadó; 1973.

64. Prieto O, del Arco M, Rives V. Structural evolution upon heating of sol-gel prepared birnessites. Thermochim Acta. 2003;401:95-109.

65. Russell JD, Fraser AR. Infrared methods. In: Wilson MJ, editor. Clay mineralogy: spectroscopic and chemical determinative methods. London: Chapman \& Hall; 1994. p. 11-67.

66. Chukanov NV. Infrared spectra of mineral species. Extended library. Dodrecht: Springer; 2014.

67. Mazzetti L, Thistlethwaite PJ. Raman spectra and thermal transformations of ferrihydrite and schwertmannite. J Raman Spectrosc. 2002;33:104-11.

68. Walter D. Characterization of synthetic hematite pigments. Thermochim Acta. 2006;445:195-9.

69. Vallina B, Rodriguez-Blanco JD, Brown AP, Benning LG, Blanco JA. Enhanced magnetic coercivity of $\alpha-\mathrm{Fe}_{2} \mathrm{O}_{3}$ obtained from carbonated 2-line ferrihydrite. J Nanopart Res. 2014;16:2322.

70. van der Marel HW, Beutelspacher H. Atlas of infrared spectroscopy of clay minerals and their admixtures. Amsterdam: Elsevier; 1976. 
71. Chernyshova IV, Hochella MF, Madden AS. Size-dependent structural transformations of hematite nanoparticles. 1. Phase transition. Phys Chem Chem Phys. 2007;9:1736-50.

72. Campbell AS, Schwertmann U, Campbell PA. Formation of cubic phases on heating ferrihydrite. Clay Miner. 1997;32: 615-22.

73. Grogan KL, Gilkes RJ, Lottermoser BG. Maghemite formation in burnt plant litter at East Trinity, North Queensland, Australia. Clays Clay Miner. 2003;51:390-6.

74. Paterson E, Swaffield R. Influence of adsorbed anions on the dehydroxylation of synthetic goethite. J Therm Anal. 1980;18: $161-7$.

75. Gualtieri AF, Venturelli P. In situ study of the goethite-hematite phase transformation by real-time synchrotron powder diffraction. Am Miner. 1999;84:895-904.

76. Frost RL, Ding Z, Ruan HD. Thermal analysis of goethite. Relevance to Australian indigenous art. J Therm Anal Calorim. 2003;71:783-97.

77. Mørup S, Meaz TM. Bender Koch C, Hansen HCB. Nanocrystallinity induced by heating. Z. Phys D. 1997;40:166-9.

78. Ruan HD, Frost RL, Klopproge JT. The behavior of hydroxyl units of synthetic goethite and its dehydroxylated product hematite. Spectrochim Acta A. 2001;57:2575-86.

79. Walter D, Buxbaum G, Laqua W. The mechanism of the thermal transformation from goethite to hematite. $\mathrm{J}$ Therm Anal Calorim. 2001;63:733-48.

80. Carlson L, Schwertmann U. Natural ferrihydrites in surface deposits from Finland and their association with silica. Geochim Cosmochim Acta. 1981;45:421-9.

81. Vempati RK, Loeppert RH, Sittertz-Bhatkar H, Burghardt RC. Infrared vibrations of hematite formed from aqueous- and drythermal incubation of Si-containing ferrihydrite. Clays Clay Miner. 1990;38:294-8.

82. Campbell AS, Schwertmann U, Stanjek H, Friedl J, Kyek A, Campbell PA. Si incorporation into hematite by heating Si-ferrihydrite. Langmuir. 2002;18:7804-9.

83. Stanjek H, Weidler PG. The effect of dry heating on the chemistry, surface area, and oxalate solubility of synthetic 2-line and 6-line ferrihydrites. Clay Miner. 1992;27:397-412.

84. Michel FM, Barrón V, Torrent J, Morales MP, Serna CJ, Boily J-F, Liu Q, Ambrosini A, Cismasu AC, Brown GE Jr. Ordered ferrimagnetic form of ferrihydrite reveals links among structure, composition, and magnetism. PNAS. 2010;107:2787-92.

85. Przepiera K, Przepiera A. Kinetics of thermal transformations of precipitated magnetite and goethite. J Therm Anal Calorim. 2001;65:497-503.

86. Liu HL, Chen T, Zou X, Qing C, Frost RL. Thermal heating of natural goethite: thermal transformation and physical properties. Thermochim Acta. 2013;568:115-21.

87. Ford RG, Bertsch PM. Distinguishing between surface and bulk dehydration-dehydroxylation reactions in synthetic goethites by high-resolution thermogravimetric analysis. Clays Clay Miner. 1999;47:329-37.
88. Wolska E, Schwertmann U. Nonstoichiometric structures during dehydoxylation of goethite. Z Kristalogr. 1989;189:223-37.

89. Peterson KM, Heaney PJ, Post JE, Eng PJ. A refined monoclinic structure for a variety o "hydrohematite". Am Mineral. 2015;100:570-9.

90. Ruan HD, Frost RL, Kloprogge JT, Duong L. Infrared spectroscopy of goethite dehydroxylation III. FT-IR microscopy of in situ study of the thermal transformation of goethite to hematite. Spectrochim Acta. 2005;58:967-81.

91. Sawaby A, Moharram MA, Shabaka AA, El Saker N. Spectroscopic method for the determination of crystallinity of hematite. Proc Indian Acad Sci (Chem Sci). 1989;101:529-38.

92. Kustova GN, Burgina EB, Sadykov VA, Poryvaev SG. Vibrational spectroscopic investigation of the goethite thermal decomposition products. Phys Chem Miner. 1992;18:379-82.

93. Burgina EB, Kustova GN, Tsybulya SV, Kryukova GN, Litvak GS, Isupova LA, Sadykov VA. Structure of the metastable modification of iron(III) oxide. J Struct Chem. 2000;41: 396-402.

94. Shaheen WM, Hong KS. Thermal characterization and physicochemical properties of $\mathrm{Fe}_{2} \mathrm{O}_{3}-\mathrm{Mn}_{2} \mathrm{O}_{3} / \mathrm{Al}_{2} \mathrm{O}_{3}$ systems. J Therm Anal Calorim. 2002;68:289-306.

95. Wyderko-Delekta M, Bolewski A. Mineralogy of ore pellets and sinters. Kraków: AGH; 1995 (in Polish).

96. Jouhari AK. Sintering of ore fines-principles and a few case studies. In: Misr VN, Reddy PSR, Mohapatr BK, editors. Mineral characterisation and processing. New Delhi: Allied Pub; 2004. p. 237-44.

97. Gupta RC. Theory and laboratory experiments in ferrous metallurgy. New Delhi: PHI; 2010.

98. Fan J, Qui G, Jiang T, Guo Y, Yang Y, Cai M. Studies on alternative blast furnace burden structure with high proportion sinter. In: Jiang T, Hwang J-Y, Masset P, Yucel O, Padilla R, Zhou $\mathrm{G}$, editors. 3rd international symposium on high temperature metallurgical processing. Hoboken: Wiley; 2012. p. 59-66.

99. Toner BM, Berquó TS, Michel FM, Sorensen JV, Templeton AS, Edwards KJ. Mineralogy of iron microbial mats from Loihi Seamount. Front Microbiol. 2012;3:1-18.

100. Watari F, Van Landuydt J, Delavignette P, Amelincx S. Electron microscopic study of dehydration transformations. I. Twin formation and mosaic structure in hematite derived from goethite. J Solid State Chem. 1979;29:137-50.

101. Cudennec Y, Lecerf A. Topotactic transformations of goethite and lepidocrocite into hematite and maghemite. Solid State Sci. 2005;7:520-9.

102. Gialanella S, Girardi F, Ischia G, Lonardelli I, Mattarelli M, Montagna M. On the goethite to hematite phase transformation. J Therm Anal Calorim. 2010;102:867-73.

103. Derie R, Ghodsi M, Calvo-Roche C. DTA study of the dehydration of synthetic goethite $\alpha \mathrm{FeOOH}$. J Therm Anal. 1976;9:435-40. 